\begin{abstract}
UNIVERSIDADE DE SÃO PAULO
FACULDADE DE FILOSOFIA, LETRAS E CIÊNCIAS HUMANAS DEPARTAMENTO DE LETRAS MODERNAS

PROGRAMA DE PÓS-GRADUAÇÃO EM LÍNGUA E LITERATURA ITALIANA
\end{abstract}

RAFFAELLA CAIRA

O ITALIANO FALADO EM CURITIBA POR UM GRUPO DE FALANTES NATIVOS QUE VIVEM NO BRASIL HÁ CERCA DE CINQUENTA ANOS

São Paulo

2009 


$$
\text { UNIVERSIDADE DE SÃO PAULO }
$$

FACULDADE DE FILOSOFIA, LETRAS E CIÊNCIAS HUMANAS

DEPARTAMENTO DE LETRAS MODERNAS

PROGRAMA DE PÓS-GRADUAÇÃO EM LÍNGUA E LITERATURA ITALIANA

\title{
O ITALIANO FALADO EM CURITIBA POR UM GRUPO DE FALANTES NATIVOS QUE VIVEM NO BRASIL HÁ CERCA DE CINQUENTA ANOS
}

\author{
RAFFAELLA CAIRA
}

\begin{abstract}
Dissertação apresentada ao Programa de Pós- Graduação em Língua e Literatura Italiana, do Departamento de Letras Modernas da Faculdade de Filosofia, Letras e Ciência Humanas da Universidade de São Paulo, para obtenção do título de Mestre em Letras.

Orientadora: Prof ${ }^{\text {a. }}$ Dr $^{\text {a. }}$ Olga Alejandra Mordente
\end{abstract}


Dedico este trabalho ao Germano, meu marido e meu grande amigo, que desde sempre, me acompanha e está ao meu lado, dando-me força para superar todos os momentos difíceis e também à amada Giorgia, fruto do nosso grande amor e da nossa cumplicidade. 


\section{AGRADECIMENTOS}

Agradeço a toda a minha família que, mesmo longe, esteve sempre presente, particularmente ao meu querido pai Beniamino, que sempre acreditou nas minhas capacidades e me estimulou a alcançar novos objetivos.

À Profa. Dra. Olga Alejandra Mordente, pela compreensão, disponibilidade, apoio e orientação.

À Profa. Dra. Lucia Sgobaro Zanette do DELEM - UFPR, pelos conselhos, amizade e estímulo ao longo deste trabalho.

À amiga, Profa. Karine Marielly Rocha da Cunha do DELEM - UFPR, pelo constante apoio e pela grande ajuda.

Ao amigo Gerson Stella, pelo carinho e pelas horas de dedicação absoluta.

Ao Oscar e a Arnalda que acreditaram desde o começo na importância deste projeto.

A todos os meus amigos que acompanharam os meus momentos de alegria e tristeza.

Aos italianos entrevistados, pela confiança, compreensão e colaboração absoluta. 


\section{RESUMO}

No final do século XIX e durante o século XX, a história do Brasil se caracterizou pela intensa imigração de homens e mulheres de diferentes idades, provenientes de muitas partes do mundo e que procuravam aqui um lugar para viver, trabalhar e encontrar condições de vida menos duras do que aquelas presentes nos lugares que, com tristeza, tiveram de deixar. Foram muitos os italianos que, desde 1875, começaram a chegar aos principais portos brasileiros. No Paraná, o fenômeno migratório teve início na mesma década, em consequência de campanhas de recrutamento que o governo paranaense promoveu a fim de atrair mão-de-obra italiana para a agricultura depois de abolida a escravidão. De fato, a partir daquela data, inúmeros italianos originários sobretudo das regiões setentrionais da Itália se estabeleceram primeiramente ao longo do litoral paranaense e, mais tarde, nos arredores da capital Curitiba, criando inúmeras colônias onde viviam de acordo com os usos e costumes da pátria-mãe.

Mediante a realização de uma série de entrevistas, este estudo se propõe a analisar o léxico usado por um grupo de italianos, que vive na cidade de Curitiba, no Paraná, e que emigrou para cá ao fim da Segunda Guerra Mundial, no período compreendido entre o final dos anos quarenta e o início dos anos setenta. Nosso objetivo será também o de estabelecer quanto a língua italiana foi preservada por eles ou quanto o idioma sofreu interferências da língua portuguesa depois de vários anos de vida em um outro país.

Os indivíduos entrevistados têm em comum diversas características: na realidade, além de viverem na mesma cidade, eles podem ser considerados bilíngues, ainda que falem quotidianamente apenas a língua portuguesa. Alguns deles chegaram a Curitiba no começo da adolescência e, bem depressa, para melhor se integrarem, abandonaram o uso da língua italiana, até mesmo em casa, e adotaram o português como nova língua materna. Outros, tendo chegado já adultos e depois de se casarem com pessoas da localidade, preferiram utilizar quotidianamente e ensinar aos próprios filhos a língua portuguesa em lugar da italiana. A maior parte deles mantém contato com a Itália e com o idioma italiano por meio de cursos de língua, encontros com outras pessoas pertencentes à comunidade ou simplesmente lendo livros ou assistindo à televisão italiana. Além disso, a muitos deles, por diversas razões, ligadas à guerra ou à impossibilidade econômica, não completou os estudos.

Após um longo período de permanência fora da Itália constatamos, naturalmente, uma perda no repertório lexical de origem e a presença de algumas interferências da língua portuguesa na língua italiana falada. Fenômeno este amplamente justificado pelos quase cinquenta anos de vida longe da terra natal. Os fatores que determinam a manutenção ou a perda dependem da aproximação ou do distanciamento que os indivíduos mantêm com a comunidade italiana residente em Curitiba ou com a Itália e também do seu grau de escolaridade. Entretanto, apesar da clara influência da língua portuguesa sobre a italiana, podemos considerar que o italiano falado hoje pelos indivíduos objeto deste trabalho se preservou bem.

Palavras-chave: Imigração. Italiano. Português. Bilingüismo. Erosão lingüística. 


\section{ABSTRACT}

By the end of the XIX century and during the XX century, the history of Brazil was characterized by the intense immigration of men and women from different ages, who came from several parts of the world. These people were looking for a place to live, work and have better life conditions, in opposition to the hard life they had in the places they sadly left. A huge number of Italians has arrived in the main Brazilian harbours since 1875. In Parana, the emigration movement started in the same decade, as a consequence of recruitment campaigns promoted by the state government in order to bring Italian labors to the agriculture after the slavery abolition. Actually, from that date, lots of Italians who came especially from the north of Italy established themselves along the coast of Parana at first. Later, the Italian also went to the outskirts of Curitiba and created many colonies where they lived according to their nation's habits and customs.

The present study has the intention of analyzing the lexicon used by a group of Italians through a series of interviews. These Italians, who live in the city of Curitiba, in Parana, emigrated to this region in the end of the Second World War, in the period between the end of the forties and the beginning of the sixties. Our objective is also to analyze how much of the Italian language was preserved by them or the intensity of the Portuguese language interferences in their mother tongue after several years of living in another country.

The interviewed people have many characteristics in common. In fact, besides living in the same city, they can be considered bilingual, even if they speak only the Portuguese language in their daily life. Some of them arrived in Curitiba in the beginning of their teen years. In order to interact better to others, they quickly abandoned the Italian language and adopted the Portuguese as their new mother tongue, even at home. Other immigrants came at an older age and, after getting married to Brazilian natives, preferred to use and teach their own children the Portuguese language instead of the Italian. Most of the interviewed Italians keep in contact with Italy and the Italian language through language courses, meetings with other people from the same community or just by reading books or watching the Italian TV channel. In addition, most of them did not finish their studies due to the war or financial problems.

After being such a long period out of Italy we could certainly notice the loss in the original lexicon and the presence of some Portuguese interference in the Italian spoken. This fact can be explained by the fifty years living far from their homeland. The factors that determine the language continuation or its loss depend on the proximity or detachment these people keep with Italy or with the Italian community that lives in Curitiba, and also their schooling level. Despite the strong Portuguese influence on the Italian language, we can consider the Italian spoken nowadays by the interviewed people in this paper has been well preserved.

Key-words: Immigration. Italian language. Portuguese language. Bilingualism. Linguistic Attrition. 


\section{RIASSUNTO}

Alla fine del XIX secolo e durante il XX secolo la storia del Brasile è stata caratterizzata da una forte immigrazione di uomini e donne di diverse età, provenienti da molte parti del mondo che cercavano qui un luogo dove vivere, lavorare e trovare condizioni di vita meno dure dei luoghi che, con tristezza, dovevano lasciare. Molti furono gli italiani che già dal lontano 1875 cominciarono ad arrivare nei principali porti brasiliani.

II fenomeno migratorio cominciò in Paranà nella stessa decade, in seguito alle campagne di reclutamento che il governo paranaense promosse per attrarre dall'Italia mano d'opera da destinare all'agricoltura dopo l'abolizione della schiavitù. Infatti a partire da quella data numerosi italiani provenienti soprattutto dalle regioni settentrionali dell'Italia si stanziarono lungo il litorale paranaense prima e nei dintorni della capitale Curitiba poi, creando numerose colonie nelle quali vivevano rispettando usi e costumi della madrepatria.

Attraverso la realizzazione di una serie di interviste, il seguente studio si propone l'obiettivo di analizzare il lessico utilizzato da un gruppo di italiani, che vive in Paraná nella cittá di Curitiba e che qui emigró dopo la fine della Seconda Guerra Mondiale, nel periodo compreso tra la fine degli anni Quaranta e gli inizi degli anni Settanta. Nostro obiettivo è anche quello di stabilire quanto la lingua italiana sia stata da loro conservata o quanto questa sia stata influenzata dalla lingua portoghese dopo numerosi anni di vita in un altro Paese.

I soggetti intervistati condividono diverse caratteristiche: infatti oltre a vivere nella stessa città, essi possono essere considerati bilingui, sebbene parlino quotidianamente soltanto la lingua portoghese. Alcuni di loro sono arrivati a Curitiba all'inizio dell'adolescenza e, ben presto, per potersi integrare meglio, hanno abbandonato l'uso della lingua italiana, anche in casa, ed hanno adottato la lingua portoghese come nuova lingua madre. Altri, pur essendo arrivati già adulti, in seguito a matrimoni con locali, hanno preferito utilizzare quotidianamente ed insegnare ai propri figli la lingua portoghese al posto di quella italiana. La maggior parte di loro mantiene contatto con l'Italia e con la lingua italiana attraverso corsi di lingua, incontri con altre persone facenti parte della comunitá o semplicemente leggendo libri o guardando la televisione italiana. Inoltre, la maggior parte di loro, per diverse ragioni, legate alla guerra o all'impossibilitá economica, non ha compiuto gli studi superiori.

Dopo un lungo periodo di permanenza fuori dall'Italia abbiamo constatato, naturalmente, una perdita parziale nel repertorio lessicale di origine e la presenza di alcune interferenze della lingua portoghese nella lingua italiana orale. Fenomeno questo ampiamente giustificato dai circa cinquanta anni di lontananza dalla terra di origine. I fattori che determinano la manutenzione o la perdita della lingua madre dipendono dalla prossimità o dalla lontananza che i soggetti intervistati mantengono con la comunità italiana residente a Curitiba o con l'Italia ed anche dal grado di scolarità dell'individuo. Tuttavia, nonostante la chiara influenza della lingua portoghese sulla lingua italiana, possiamo considerare che l'italiano parlato oggi dagli individui oggetto di questo lavoro si è conservato abbastanza bene.

Parole chiave: Immigrazione. Italiano. Portoghese. Bilinguismo. Erosione linguistica. 


\section{LISTA DE TABELAS}

TABELA 4.1 - Normas para transcrição 38

TABELA 4.2 - Entrevista 1 45

TABELA 4.3 - Entrevista 2 50

TABELA 4.4 - Entrevista 3 60

TABELA 4.5 - Entrevista 4 66

TABELA 4.6 - Entrevista 5 73 


\section{SUMÁRIO}

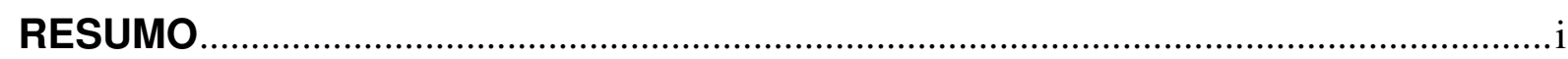

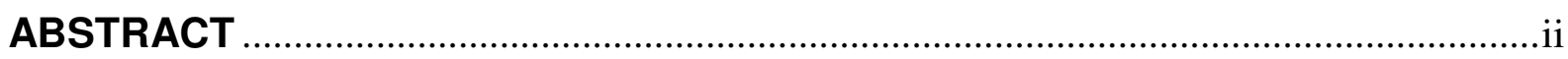

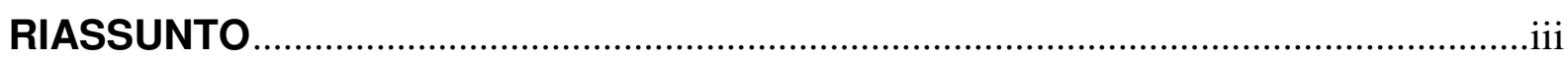

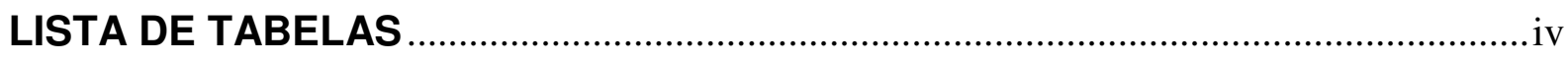

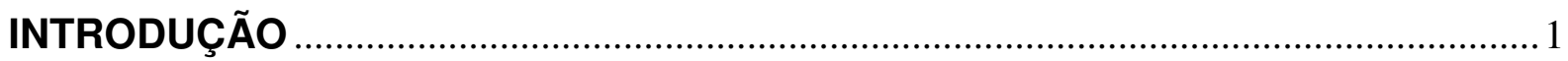

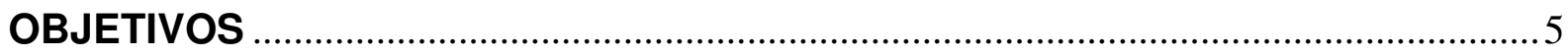

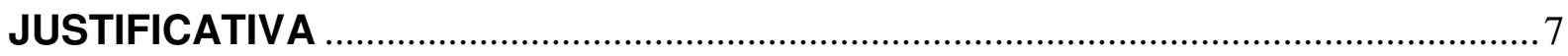

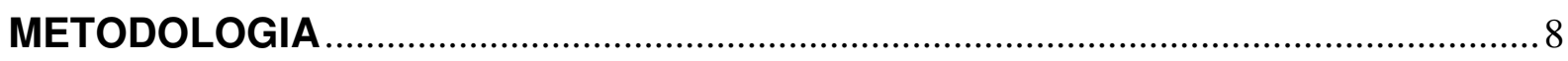

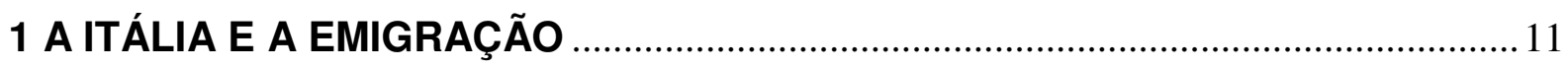

1.1 CAUSAS E NÚMEROS DA EMIGRAÇÃO ITALIANA ............................................ 12

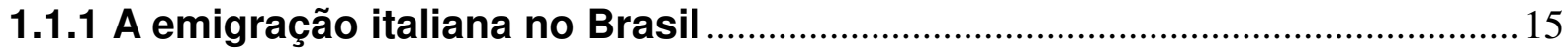

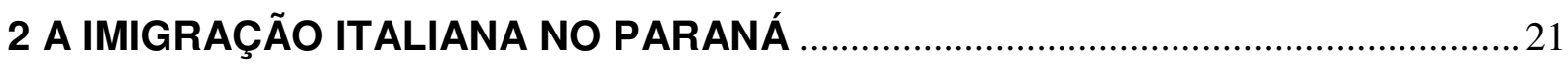

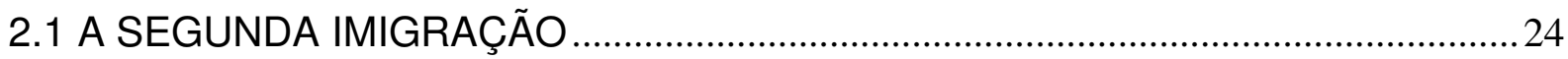

3 SITUACÃO LINGUÍSTICA DA ITÁLIA NA ÉPOCA DA GRANDE EMIGRAÇÃO. 26

3.1 PROBLEMAS CULTURAIS E LINGUÍSTICOS NA ITÁLIA PÓS-UNIFICAÇÃO .. 26

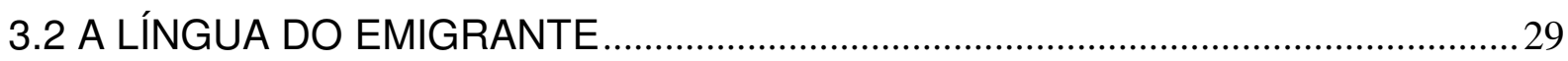

4 O ITALIANO E SUAS TRANSFORMAÇÕES. TRANSCRIÇÃO E ANÁLISE DAS

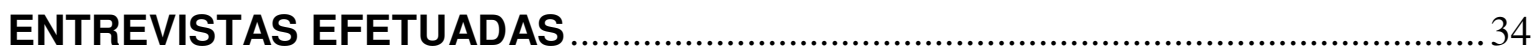

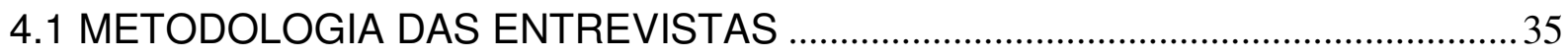

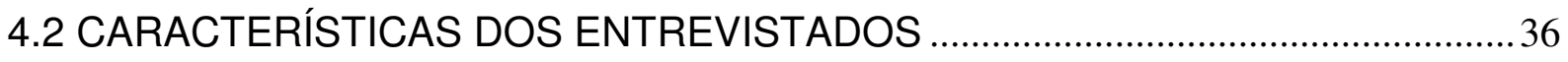

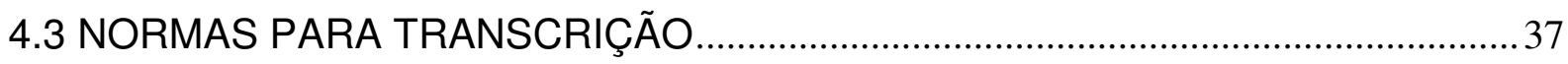

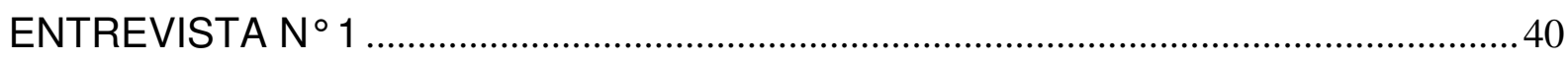

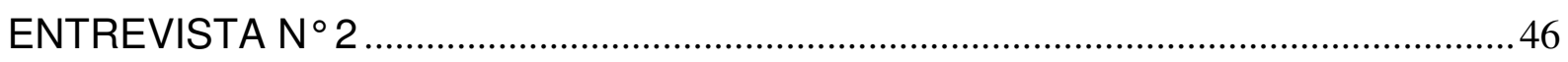

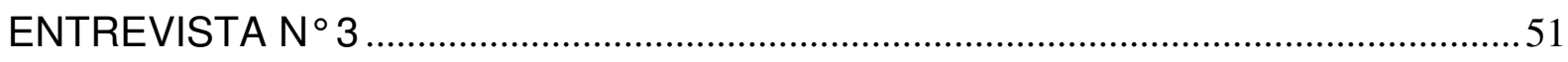

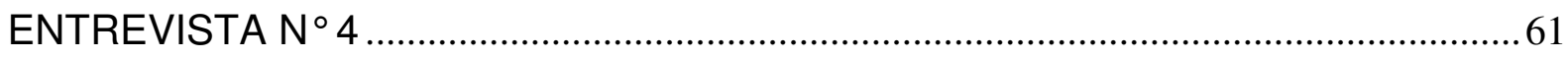

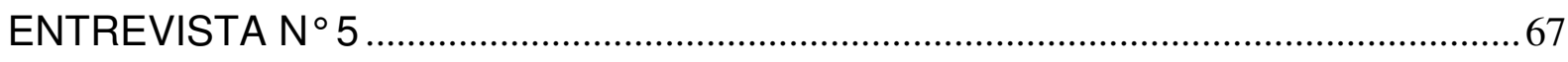

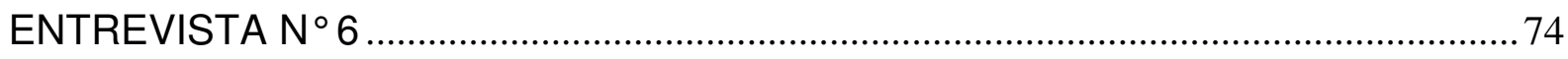

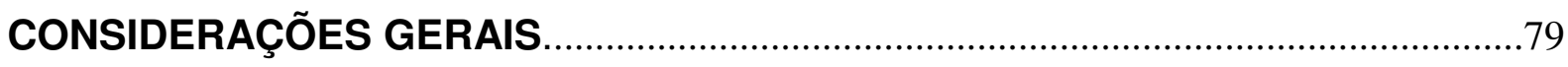

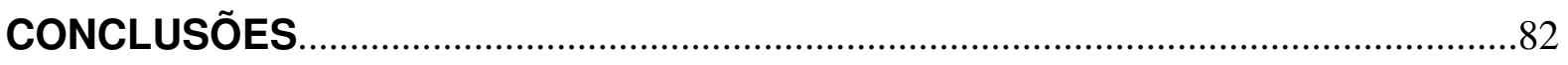

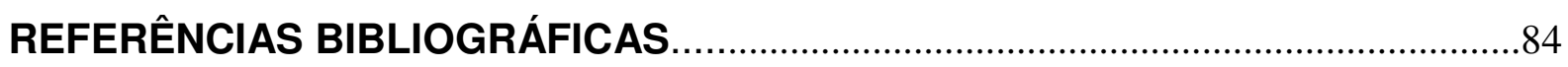

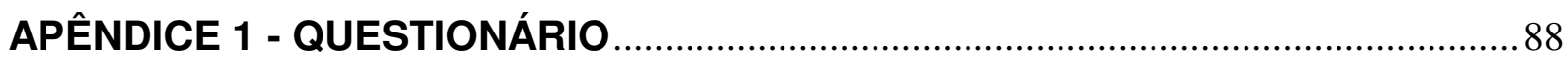




\section{INTRODUÇÃO}

Segundo dados da Embaixada Italiana em Brasília, que constam do documento: Presenza italiana in Brasile - cenni sulle collettività, os cidadãos italianos inscritos na AIRE (Associazione Italiana Residenti all'Estero) passam de 308.000, mais da metade dos quais vive nas regiões Sul e Sudeste do Brasil. Ainda de acordo com a mesma fonte, a população brasileira "oriunda" é estimada em 25 milhões de pessoas, aproximadamente $15 \%$ da população brasileira.

A emigração italiana no Brasil remonta ao século XVI. Tratava-se então de navegantes, exploradores, aventureiros, missionários, soldados e pequenos comerciantes que se instalaram principalmente na região costeira que vai do Rio de Janeiro a Belém. Entretanto, até o fim do século XIX o fluxo migratório italiano fora de modestas dimensões. De fato o censo brasileiro de 1872 registrou a presença de apenas 6.000 italianos residentes em todo o país. A grande imigração italiana no Brasil iniciou propriamente no final do século XIX sob pressões abolicionistas que levaram o governo brasileiro a promover a imigração maciça de homens livres destinados às plantações agrícolas no lugar da mão-de-obra escrava. À grande demanda brasileira correspondeu o clímax da crise italiana que se seguiu à unificação do país em 1861. Problemas de ordem social, política e econômica começaram, de fato, a interferir diretamente na vida do cidadão da época, deixandoo sem possibilidade de continuar vivendo dignamente no próprio país.

Para atenuar a difícil situação interna, o governo italiano não viu outra alternativa a não ser enviar os próprios cidadãos para novos mundos, em busca de novas terras, por meio de uma série de acordos, previamente assinados, com os governantes de alguns países, entre eles o Brasil. Tais acordos garantiam aos italianos apoio e assistência in loco além de trabalho e de um lugar para dormir. Diante dessa situação e sem outras alternativas, milhares de italianos aceitaram partir para o desconhecido, na esperança de encontrar nessas novas terras aquilo que a Itália não podia mais oferecer-lhes e atraídos por uma propaganda algumas vezes enganosa, que mostrava o novo mundo como lugar do resgate e do renascimento.

Mas logo depois da sua chegada esses emigrantes puderam verificar que as promessas não eram totalmente verdadeiras: foram muitos os problemas que os pioneiros desta aventura tiveram de enfrentar, problemas ligados às condições de 
trabalho, que não eram as esperadas, à remuneração que lhes garantia apenas a sobrevivência, às condições climáticas que eram desfavoráveis e tornavam difícil a sua adaptação.

Os imigrantes que chegaram nas ondas sucessivas encontraram melhores condições de vida, graças aos esforços dos pioneiros que prepararam um ambiente mais propício e lutaram pelo reconhecimento do seu trabalho. Deve-se ressaltar, no entanto, que nem sempre a sua adaptação foi facilitada por quem já vivia no Brasil há algum tempo. Ao contrário, os novos imigrantes, que eram cultural, econômica e socialmente diferentes dos primeiros, tiveram de enfrentar inúmeras dificuldades.

De acordo com o que afirma Angelo Trento no livro Do outro lado do Atlântico: "Os recém-chegados provocaram tantos rancores, tanta desconfiança, tanta animosidade nos que residiam há anos no país [....] As causas dessa situação foram substancialmente três: culturais, políticas e de geração."

Apesar disso, a imigração começou a ser vista, a partir daquele momento, como uma boa alternativa seja para os "oriundi", seja para aqueles que os acolhiam e que podiam, assim, enriquecer com a sua experiência profissional. Impossível dizer, diante desses fatos, quão significativa tenha sido a presença dos italianos no desenvolvimento da história brasileira, do fim do século XIX até os nossos dias. Aos italianos si atribui o aumento da produção e o aperfeiçoamento das práticas econômicas nas cidades onde se estabeleceram, além do incremento das indústrias, seja com a oferta de mão-de-obra, seja com o investimento para a criação de novas fábricas. Eles modificaram, além disso, a fisionomia urbana por meio de suas técnicas arquitetônicas; contribuíram para a modernização das cidades e influenciaram os campos da música, do esporte e da educação, deixando a sua marca em cada setor.

Levando em consideração tudo o que se disse até o momento e tendo em vista a grande presença de italianos no território brasileiro, os estudos que se podem fazer sobre esse assunto são inúmeros. O trabalho em questão tem o objetivo de estudar o léxico utilizado por alguns indivíduos pertencentes à comunidade italiana que se estabeleceram na cidade de Curitiba ao final da Segunda Guerra Mundial; de verificar, então, quanto a língua italiana se conservou depois de muitos anos de vida no Brasil.

Curitiba, capital do estado do Paraná, concentra um grande número de imigrantes italianos, muitos dos quais chegaram no período sucessivo à Segunda 
Guerra. Por meio de uma série de entrevistas se procurará ter uma visão geral do que acontece do ponto de vista linguístico a indivíduos que vivem há mais de cinquenta anos em um novo país e que estão, portanto, sujeitos às interferências de uma segunda língua.

O presente trabalho se subdivide em quatro capítulos:

No primeiro, será apresentado um quadro geral da emigração italiana, quando e por que começou e quais foram os países aos quais os italianos se dirigiram, para ter uma ideia mais clara das proporções deste vasto fenômeno. Aí também será abordado o tema da emigração italiana para o Brasil: o que induziu os italianos a desembarcar no território brasileiro e qual foi a sua história neste país. Entre os estudos anteriormente feitos sobre o assunto se fará referência sobretudo ao livro: Do outro lado do Atlântico, de Angelo Trento.

No segundo, será traçada a história da emigração italiana em território paranaense, da chegada dos primeiros colonos e da formação dos primeiros assentamentos até a imigração mais recente (tais estudos serão efetuados levando em conta trabalhos anteriores publicados por grandes estudiosos como, por exemplo, Altiva Pilatti Balhana e Stefano Ferrarini).

Serão apresentadas as razões que levaram o governo paranaense a recrutar tantos imigrantes e quais eram as tarefas que os esperavam, observando as dificuldades por eles enfrentadas e os seus sucessos. Além disso, serão destacadas as diferenças entre a primeira onda migratória, que vai das últimas três décadas do século XIX até os anos que precedem o início da Primeira Guerra Mundial, e a segunda onda, que vai dos anos seguintes ao final da Segunda Guerra até os anos setenta do século XX. Serão também apresentadas as diferenças entre o primeiro e o segundo emigrante, cujas condições econômicas, socioculturais e de trabalho eram certamente diferentes.

No terceiro capítulo, será apresentada o momento linguístico em que se encontrava a Itália neste século de emigração, levando-se em conta, de um lado, a grande força que os dialetos tinham na época em que partiram os pioneiros e, de outro, a grande vontade de alguns de impor uma língua comum, símbolo de unidade e de união nacional, que, de todo modo, demorou para se afirmar. Serão também analisadas as diferenças linguísticas entre os primeiros imigrantes, cuja língua era quase exclusivamente o dialeto, e os segundos, já capazes de usar, graças à instrução escolar, um italiano padrão. 
No quarto e último momento, serão apresentadas as entrevistas feitas com alguns italianos residentes há cerca de cinquenta anos na cidade de Curitiba e será proposta uma análise minuciosa relativa ao léxico usado por eles, a fim de poder definir quanto a língua italiana efetivamente se conservou depois de vários anos de vida no Brasil e quanto esse idioma sofreu interferências da língua portuguesa. Tal análise será feita tendo presente alguns estudos e algumas considerações feitas anteriormente por estudiosos e pesquisadores de várias universidades brasileiras, entre eles os trabalhos sobre a comunidade italiana presente no Estado de São Paulo, feitos pelas Professoras Doutoras Loredana de Stauber Caprara, Olga Alejandra Mordente e Giliola Maggio, da Universidade de São Paulo (USP), assim como os trabalhos feitos pelo Professor Doutor Tommaso Raso da Universidade Federal de Minas Gerais.

A transcrição ortográfica das entrevistas terá como base as normas do Projeto Norma Urbana Culta - NURC, conhecido em âmbito nacional, cujo objeto principal é o estudo da língua culta falada no Brasil.

Espera-se que este estudo possa ser útil para novas pesquisas sobre o aspecto linguístico das comunidades italianas presentes na cidade de Curitiba, em particular, e no estado do Paraná, em geral. 


\section{OBJETIVOS}

Revendo o que anteriormente se escreveu sobre as comunidades italianas presentes em território paranaense, notou-se que a maior parte dos estudiosos concentrou a própria atenção nas causas e nas motivações que levaram centenas de milhares de italianos a chegar ao estado. Esses trabalhos também deram atenção às comunidades mais antigas presentes no Paraná, entre as quais a colônia de Santa Felicidade, que se encontra a aproximadamente sete quilômetros de Curitiba, e a colônia Antonio Chaves, pertencente ao município de Colombo. Faltam, assim, estudos recentes sobre a segunda onda migratória, sobre os últimos imigrantes, vale dizer sobre aqueles que chegaram ao Paraná logo depois da Segunda Guerra Mundial. Estes, tendo se integrado perfeitamente ao tecido urbano curitibano e não tendo se isolado no interior das colônias, como acontecera com os pioneiros, passaram quase despercebidos. Poucos são conhecidos, é difícil encontrá-los e reconstruir a sua história.

Mediante a realização de uma série de entrevistas, este estudo se propõe a analisar o léxico usado por um grupo de italianos, que vive na cidade de Curitiba, no Paraná, e que emigrou para cá ao fim da Segunda Guerra Mundial, no período compreendido entre o final dos anos quarenta e o início dos anos setenta. Nosso objetivo será também o de estabelecer quanto a língua italiana foi preservada por eles ou quanto o idioma sofreu interferências da língua portuguesa depois de vários anos de vida em um outro país.

Os indivíduos entrevistados têm em comum diversas características: na realidade, além de viverem na mesma cidade, eles podem ser considerados bilíngues, ainda que falem quotidianamente apenas a língua portuguesa. Alguns deles chegaram a Curitiba no começo da adolescência e, bem depressa, para melhor se integrarem, abandonaram o uso da língua italiana, até mesmo em casa, e adotaram o português como nova língua materna. Outros, tendo chegado já adultos e depois de se casarem com pessoas da localidade, preferiram utilizar quotidianamente e ensinar aos próprios filhos a língua portuguesa em lugar da italiana. A maior parte deles mantém contato com a Itália e com o idioma italiano por 
meio de cursos de língua, encontros com outras pessoas pertencentes à comunidade ou simplesmente lendo livros ou assistindo à televisão italiana.

Além disso, a maior parte deles, por diversas razões, ligadas à guerra ou à impossibilidade econômica, não completou os estudos.

Por meio desta análise se procurará verificar as interferências da língua portuguesa sobre a língua italiana oral e determinar a que se deve esse fenômeno, levando-se em conta, de um lado, a vontade de não esquecer a própria língua materna e, de outro, a consciência de que, para se integrar em um novo país, é preciso aprender não só a viver como os nativos mas também a se comunicar na língua deles. 


\section{JUSTIFICATIVA}

Segundo estimativas das autoridades consulares, a comunidade de origem italiana atualmente presente na circunscrição consular de Curitiba, que compreende os estados do Paraná e de Santa Catarina, é de cerca 4 milhões de pessoas. A quase totalidade dos imigrantes italianos que chegaram ao território paranaense provém das regiões do Norte da Itália, em particular do Vêneto: na verdade, eles encontraram nesse estado as condições ideais para poder continuar a tradição agrícola que sempre os acompanhou e da qual faziam parte.

Os estudos feitos até o momento sobre a comunidade italiana no Paraná evidenciaram essencialmente o aspecto histórico, demográfico, socioeconômico e cultural. Esses mesmos estudos revelaram como, mais de 130 anos depois da chegada das primeiras comitivas de italianos ao porto de Paranaguá, a cultura dos descendentes dos primeiros imigrantes se transformou consideravelmente, integrando-se em parte ao mosaico cultural brasileiro. Mas seus efeitos são ainda evidentes na persistência do folclore de origem, nas diversas festas, encontros, manifestações que frequentemente se realizam. Porém, pouco se sabe sobre o grande patrimônio linguístico desta comunidade e sobre como a língua italiana se conservou depois de anos de vida no Brasil. A vontade de contribuir para a reconstrução da história dos imigrantes italianos que se estabeleceram no Paraná, em Curitiba, seja do ponto de vista sociocultural ou do estritamente linguístico, é, pois, a base deste trabalho.

A fim de efetuar uma análise mais completa do fenômeno, serão analisados os estudos que há anos os docentes e pesquisadores da USP têm feito sobre 0 tema. De seus trabalhos e publicações se extrai uma visão muito particularizada de um determinado aspecto da emigração italiana no Brasil: o aspecto linguístico da comunidade italiana presente no estado de São Paulo. Tais estudos jogam luz sobre o processo de conservação ou transformação da língua italiana e explicam as causas e os porquês dele.

Então, tendo como referência os dados fornecidos por esses estudiosos, este trabalho se justifica pela vontade de dar uma nova contribuição a este amplo tema, pela necessidade de entender a importância deste fenômeno em um estado, o Paraná, e em uma cidade, Curitiba, onde ainda pouco se sabe sobre os imigrantes. 


\section{METODOLOGIA}

O corpus deste trabalho é constituído de uma série de seis entrevistas feitas a um grupo de italianos que emigrou para o Brasil e se estabeleceu na cidade de Curitiba após a Segunda Guerra Mundial, no período compreendido entre 1948 e 1969.

$\mathrm{Na}$ verdade, nossa intenção era a de poder fazer um número maior de entrevistas, de modo a ter uma visão mais ampla dos fenômenos linguísticos verificados no interior da comunidade italiana presente na capital paranaense.

Todavia, isso não foi possível em razão da dificuldade de encontrar essas pessoas que no momento vivem em diversos bairros da cidade e são bastante reservadas e desconfiadas daqueles que têm a intenção de se aproximar para descobrir algo sobre o seu passado ou para promover estudos sobre a sua partida da Itália e a consequente chegada ao Brasil.

Graças à ajuda de um intermediário, descendente de italianos, que nos permitiu entrar em contato com várias famílias, e à sociedade "Dante Alighieri", que nos forneceu o nome de alguns integrantes da comunidade, entramos em contato com 20 pessoas.

Desde o início se explicou a eles, de modo claro, qual seria o objetivo de nossa pesquisa e como cada um deles poderia contribuir. A honestidade e sinceridade de nossas intenções provavelmente assustaram a maior parte deles. De fato das 20 pessoas contatadas, 7 se recusaram a colaborar, elencando inúmeros motivos, como falta de tempo, ou afirmando que estavam momentaneamente fora da cidade. Outros, ainda que tenham aceitado nos encontrar, ao saber da necessidade de registrar as entrevistas e de posteriormente submetê-las a uma análise linguística, decidiram não continuar. Das 20 pessoas contatadas, pois, somente 6 concordaram em ser entrevistadas. Estas, superado o constrangimento inicial, demonstraram ser extremamente colaborativas respondendo a todas as perguntas feitas e acrescentando informações que elevaram muito o nível da discussão. Nossa vontade era também entrevistar um número igual de indivíduos do sexo feminino e do sexo masculino para efetivamente verificar se a língua materna se conservou mais pelos homens do que pelas mulheres. Conseguimos localizar, entretanto, 
somente duas pessoas do sexo feminino, por isso a maior parte dos entrevistados é do sexo masculino.

A maioria deles tem aproximadamente setenta anos e passou toda a vida no Brasil. Suas regiões de origem são exclusivamente setentrionais: quatro provêm do Vêneto, um da Lombardia e um do Trentino Alto Adige.

Uma vez escolhido o grupo de pessoas a entrevistar, preparou-se uma série de perguntas para cada um dos sujeitos em questão. Tais perguntas foram pensadas de modo a percorrer de novo, junto aos protagonistas, as etapas principais de sua história: de sua partida da Itália à chegada ao Brasil, das primeiras impressões sobre este novo país aos primeiros objetivos alcançados. Deve-se esclarecer que, no momento da entrevista propriamente dita, muitas perguntas foram deixadas de lado e privilegiou-se uma conversação muito mais espontânea e emocionante, de tal modo que o entrevistado se sentisse à vontade e não constrangido na presença do gravador. O questionário, composto de 24 perguntas, serviu mais como guia e apoio na fase inicial da conversação, mas foi utilizado pouco e de forma diferente com cada um dos entrevistados.

As entrevistas foram feitas com a ajuda de um gravador digital e na casa dos entrevistados, em um ambiente previamente preparado de modo a evitar interrupções e rumores. Isso foi possível apenas em parte e muitas vezes foram necessárias interrupções e pausas. Cada entrevista durou mais ou menos 40 minutos, dos quais aproximadamente 10 foram usados para a transcrição e sucessiva análise. Foram selecionados trechos que, na nossa opinião, apresentavam maiores possibilidades de estudo. Naturalmente, em se tratando de entrevistas espontâneas, os maiores problemas se deram no momento em que o entrevistado, por exemplo, abaixava o tom de voz, acelerava o discurso ou iniciava a frase em voz alta e a terminava quase sussurrando. Tudo isso criou uma série de dificuldades que se tentou resolver da melhor forma possível.

Para a transcrição de tais entrevistas usamos como guia os estudos sobre o português falado no Brasil feitos pelo projeto NURC - Norma Urbana Culta, mas também as publicações sobre o LIP (Lessico Italiano Parlato), obra de estudiosos de várias universidades italianas sob a coordenação de Tullio De Mauro.

Gostaríamos, enfim, de salientar que o presente estudo não pretende fornecer uma visão global sobre o aspecto linguístico dos italianos que vivem na cidade de Curitiba, uma vez que o restrito número de entrevistados não permite uma visão 
completa do fenômeno, mas pretende apenas tecer uma série de considerações relativas ao léxico utilizado por um grupo de imigrantes que, depois da Segunda Guerra Mundial, escolheu esta cidade como segunda pátria e que adotou 0 português como língua a ser usada diariamente. 


\section{A ITÁLIA E A EMIGRAÇÃo}

"Se devi lasciare la tua patria, salendo sulla nave, distogli lo sguardo dai confini che ti hanno visto nascere."

(Pitágoras)

A história da emigração italiana é a história de uma sociedade antiga e fechada, presa ao turbilhão de transformações que estavam mudando as feições do país. É a história das classes pobres que caminhavam em direção à liberdade e ao bem-estar. Para ser entendida, a emigração italiana deve ser inserida na história do país como parte essencial de um crescimento que exigiu difíceis escolhas, mas que registrou também muito egoísmo e muitos erros.

Para saber como o país cresceu, para entender como se desenvolveu o capitalismo italiano, é indispensável lembrar que milhões de camponeses foram expulsos de suas terras e outros milhões de trabalhadores preferiram escolher espontaneamente, muitas vezes como sinal de protesto, uma nova pátria. Cem anos atrás, quando a emigração atingiu dimensões alarmantes, a Itália era um país em dificuldade: jovem, atrasado, inexperiente e sem matérias-primas. Na Península, construíam-se as primeiras escolas e os italianos apenas começavam a se conhecer.

Segundo afirma Delisio Villa (1997, p. 47), "Nella nuova Italia tutto era diviso: la destra tra conservazione e modernizzazione, la sinistra fra riforme e rivoluzione, $i$ socialisti fra rivendicazioni ed anarchia, i cattolici fra rifiuto e conciliazione." 2

O Estado era muito frágil e se apoiava sobre uma única classe: uma burguesia escassa, egoísta e medrosa. As classes populares não tinham direito ao voto. Para elas, o Estado era um patrão abusivo que se devia combater com todas as forças. É nesse contexto que a emigração italiana nasce. Ela é parte de um grande fenômeno que atingiu toda a Europa no século XIX e que levou aproximadamente sessenta milhões de europeus para além-mar. Esta colossal e

\footnotetext{
1 "Se você tem de deixar a sua pátria / subindo em um navio, / desvie os olhos das fronteiras / que o viram nascer." (tradução nossa)

2"Na nova Itália tudo era dividido: a direita entre conservação e modernização, a esquerda entre reformas e revolução, os socialistas entre reivindicações e anarquia, os católicos entre recusa e conciliação". (tradução nossa)
} 
tardia transmigração é, ao mesmo tempo, fruto de um impressionante aumento da população e do rápido processo de industrialização que ocorre no continente. A passagem da sociedade rural para um novo modo de viver em sociedade constitui, talvez, o maior fato histórico do século $X X$ e seguramente uma transformação decisiva na história do homem.

\subsection{CAUSAS E NÚMEROS DA EMIGRAÇÃO ITALIANA}

E io lasso 'a casa mia, lasso 'o paese, e me ne vaco ' $n$ America a zappare. Pe' fa' fortuna parto, $e$ sto nu mese senza vede cchiu' terra: cielo e mare.

E lasso 'a casa mia, l' Italia bella, pe' ghi luntano assaie, 'n terra straniera. E sotto a n' atu cielo e n' ata stella trasporto li guaglioni e la mugliera. E là accummencia la malincuinia penzanno a la campagna addo so' nato; a chella vecchia santa 'e mamma mia, e a tutt' 'e ccose care d'o passato...

(Raffaele Viviani Scalo marittimo) $^{3}$

Gente la più sedentaria, la più attaccata alla terra e al tetto che li vide nascere, la più schiava delle proprie tradizioni domestiche e campestri......, dalla sera alla mattina decidono di partire. È gente che non sa fare altro che il contadino... ${ }^{4}$

(Circolare del Prefetto di Cremona)

De acordo com as afirmações de Gian Antonio Stella e Vito Teti (2006, p. 8) foram quase 27 milhões os italianos que deixaram a Península no intervalo de um século, ou seja, de 1869, data da proclamação do Reino da Itália, a 1970. Cheios de esperança, transpuseram os Alpes e cruzaram o oceano em busca de uma nova pátria. A história da emigração italiana, porém, é muito mais antiga, se é verdade o que diz o provérbio do século XIV - "pássaros e florentinos estão em todo o mundo"

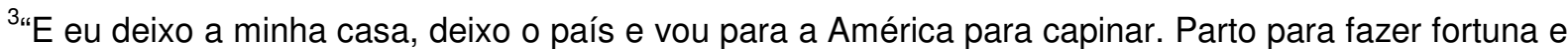
há um mês não vejo mais terra: só céu e mar. E deixo minha casa, a bela Itália, para ir tão longe, em terra estrangeira. E sob um outro céu e uma outra estrela levo os garotos e a mulher. E lá começa a melancolia pensando no campo onde nasci, naquela velha e santa mãe e em todas as coisas queridas do passado..." (tradução nossa)

4 "A gente mais sedentária e mais ligada à terra e ao teto que as viu nascer, a mais escrava das próprias tradições domésticas e campestres..., do dia para a noite decidem ir embora. É gente que não sabe fazer outra coisa do que ser camponês..." (tradução nossa)
} 
-, que Giovanni da Montecorvino, um médico milanês, encontrou, em Pequim, em 1333; e que Lyon foi, em uma certa época, uma cidade bilíngue onde se falava o francês e o italiano. O grande êxodo, porém, foi aquele que viu a Península esvaziar-se a partir das últimas três décadas do século XIX. De fato, desde os primeiros anos da unificação nacional - 1861 -, as migrações para o exterior representaram, por um longo período, um fenômeno característico da evolução demográfica, econômica e social do novo Reino. De acordo com Delisio Villa (1997, p. 52), "Il 1860 è proprio l'anno zero della nostra emigrazione. Nel 1860 inizia la lunga marcia degli italiani alla ricerca di nuovi spazi, in Europa ed in America." 5

Além disso, a maior parte da população italiana naquela época vivia em um estado de extrema pobreza. Para Angelo Trento (2000, p. 31), a miséria foi "a verdadeira e exclusiva causa da emigração transoceânica entre 1880 e a primeira guerra mundial." Realmente, uma pesquisa parlamentar dirigida por Stefano Jacini (apud STELLA; TETI, 2006, p. 10), católico moderado, por diversas vezes ministro, oferece-nos uma fotografia precisa, região por região, das condições de vida da maior parte dos italianos:

Nelle valli delle Alpi e degli Appennini, ed anche nelle pianure, specialmente nell' Italia Meridionale, e perfino in alcune province fra le meglio coltivate dell' alta Italia, sorgono tuguri ove in un' unica camera affumicata e priva di aria e luce vivono insieme uomini, capre, maiali e pollame. E tali catapecchie si contano forse a centinaia di migliaia. ${ }^{6}$

Entretanto, atribuir a origem deste imponente êxodo somente à miséria seria simplista. Não que a miséria não tenha tido o seu peso, mas deve-se considerá-la uma co-causa de motivações muito mais complexas. Angelo Trento (2000, p. 31) resume muito claramente as principais causas que levaram centenas de milhares de italianos a procurar melhores condições de vida em outros países:

A literatura sobre as causas internas da vaga emigratória transoceânica do
período $1880-1914$ é vasta: bastará acenar esquematicamente para o fato
de que o fluxo é determinado por motivos seja de ordem demográfica
(diminuição do índice de mortalidade e estabilização do índice de natalidade
após 1870), seja de ordem econômica (entre estes últimos, o primeiro lugar

\footnotetext{
5 "1860 é realmente o ano zero da nossa emigração. Em 1860 inicia a longa marcha dos italianos em busca de novos espaços, na Europa e na América." (tradução nossa)

6 "Nos vales dos Alpes e dos Apeninos, e também nas planícies, especialmente na Itália Meridional, e até mesmo em algumas províncias entre as mais bem cultivadas da alta Itália, surgem casebres onde em um único quarto esfumaçado e sem ar e luz vivem juntos homens, cabras, porcos e galinhas. E tais casebres se contam talvez em centenas de milhares". (tradução nossa)
} 
é assumido, sem dúvida, pela depressão agrícola dos anos '80, que provocou uma crise de disponibilidades alimentícias). Mas foi sobretudo a impossibilidade, para os camponeses, de conseguirem dinheiro vivo que impulsionou massas inteiras a atravessar o oceano. Todos esses fenômenos, juntamente com a taxa sobre a farinha, cujo não pagamento podia comportar o confisco da propriedade, resolveram-se numa sangria do mundo camponês. Entre 1875 e 1881 foram confiscadas 61.831 pequenas propriedades e entre 1884 e 1901, 215.759.

Bastaria este quadro desolador para demonstrar que os fatores de expulsão tinham uma incidência maior que os de atração. O êxodo não foi certamente freado pelas classes dirigentes da época que, ao contrário, viam com alívio uma emigração que constituía uma "válvula de escape para a paz social." (TRENTO, 2000, p. 31) Naturalmente havia aqueles que se mostravam contrários à emigração: em primeiro lugar os proprietários de terras, que temiam os efeitos da visível diminuição da força de trabalho ligada ao êxodo, como o aumento dos salários e contratos de trabalho mais favoráveis aos camponeses. Mas a corrente em favor da emigração, que tinha entre seus principais expoentes os armadores genoveses, intensificou-se progressivamente.

Este sucinto quadro mostra quanto era duro e difícil viver na Itália naqueles anos e como deveria ser o ânimo dos italianos diante dessa situação. A difícil situação interna e a consciência de que a Itália não tinha muito a oferecer levaram, portanto, milhões de italianos a deixarem a pátria e a dirigirem-se para novas terras. Começa, assim, um processo que ao longo de um século levaria milhões de italianos a estabelecerem-se em várias partes do mundo.

Mas quais foram as regiões de onde partiu o maior número de emigrantes e quais foram os países para onde os italianos se dirigiram? A emigração não atingiu ao mesmo tempo e em igual medida todos os territórios do Estado italiano, mas ao longo do tempo foram diversas as áreas de proveniência com importantes fluxos migratórios. Do ponto de vista temporal, foram as regiões do Norte as primeiras a serem atingidas pelo fenômeno, pois, sendo as zonas economicamente mais ricas, foram as primeiras a sentirem os desequilíbrios ligados ao desenvolvimento industrial. Quanto à extensão territorial, entretanto, foi dos territórios do Nordeste (Triveneto e Emilia) e daqueles do Sul que se verificaram fluxos mais consistentes da população. $O$ atraso da emigração meridional em relação à do norte derivou, provavelmente, de seu envolvimento mais gradual no processo de emigração, além de uma geral e menor disponibilidade de fundos indispensáveis para enfrentar as 
longas e caras viagens. Aproximadamente no fim do século XIX, o êxodo de massa do sul sofria o efeito de dois fatores conjuntos: a formação de uma nova demanda de mão-de-obra especializada nos Estados Unidos, que agiu como fator de atração, e a reestruturação dos transportes marítimos primeiramente em Nápoles e, em um segundo momento, em Palermo que, com a introdução da navegação a vapor, trouxe uma notável diminuição no tempo e no custo das viagens.

Em relação aos destinos das correntes migratórias, entre 1876 e 1885, a meta principal foi a Europa central, com cerca de 64\% dos expatriados. Os países de maior atração foram a França, a Alemanha e a Suíça. De 1885 aos anos seguintes à Primeira Guerra Mundial, assumiram um peso maior os destinos transoceânicos, representados sobretudo pelo Brasil, Argentina e Estados Unidos. Logo depois da

primeira grande guerra, a emigração continental novamente superou a transoceânica, até porque esta última sentiu o efeito das leis restritivas promulgadas por alguns países de emigração (entre eles primeiramente os Estados Unidos). Entre o fim do Segundo Conflito Mundial e a primeira metade dos anos cinquenta, os fluxos se dirigiram de maneira quase análoga a países europeus e a nações fora da Europa, para, nos anos seguintes, orientarem-se predominantemente ao mercado de trabalho europeu.

\subsubsection{A emigração italiana no Brasil}

No final do século XIX e durante o século XX, a história do Brasil se caracterizou por uma forte imigração de homens e mulheres de diversas idades, provenientes de muitas partes do mundo, que buscavam aqui um lugar para viver, trabalhar e encontrar condições de vida menos duras do que as encontradas nos países que, com tristeza, tiveram de deixar. Foram muitos os italianos que na época começaram a chegar aos portos de Santos, Rio de Janeiro e Paranaguá. Tantas histórias diferentes de uma humanidade diferente, mas unida pelo mesmo intento: a busca de um lugar onde pudesse viver dignamente a própria existência e dar uma vida digna desse nome aos próprios filhos. De acordo com Angelo Trento (2002, p. 
3): "Cartografi, marinai, religiosi, avventurieri, scultori, soldati e botanici italiani calcarono le terre dell' immensa colonia portoghese sin dal XVI secolo...."7

Entretanto, a imigração propriamente dita teve início em 1875 e, durante um século, descarregou nos portos brasileiros um milhão e meio de italianos. Como afirma Trento (2000, p. 18):

\begin{abstract}
Será a partir do fim dos anos 70 que a emigração italiana para o Brasil começará a assumir um aspecto mais preciso e dimensões apreciáveis e até a transformar-se em fenômeno de massa entre 1887 e 1902, contribuindo, de modo decisivo, para o aumento demográfico do país.
\end{abstract}

Os italianos tiveram um papel fundamental no processo de modernização do Brasil contemporâneo, participando ativamente do desenvolvimento da economia de exportação, da industrialização, dos processos de politização e nacionalização das massas. Muitos deles, talvez os mais empreendedores, abandonaram o campo, ao qual se dirigiram inicialmente, e se aventuraram nos setores de serviços, comércio, atacado e varejo, contribuindo significativamente para o rápido desenvolvimento das cidades brasileiras. Mas o caminho para chegar a esse status foi longo e doloroso, feito de ilusões e desilusões, esperanças e abandonos, saudades e uma grande força de vontade.

Mas o que levou o governo brasileiro a receber tantos imigrantes italianos e quais esperanças trouxeram um número tão elevado deles ao imenso e distante Brasil? O território brasileiro sempre apresentou um contraste extraordinário: de um lado, grandes riquezas naturais (ouro, diamantes, minerais); de outro, uma pobreza extrema de mão-de-obra, suficiente apenas para atender as necessidades básicas. Os portugueses, que dominavam a imensa colônia, procuraram resolver o problema, transportando da África milhares de escravos. Inicialmente, a mão-de-obra escrava assegurou a coleta de madeiras de lei e para manter de pé a indústria açucareira. Mais tarde ela seria usada para a criação de gado e posteriormente para a exploração das minas de ouro e diamantes. O Brasil se apresentava, pois, como um imenso cofre repleto de tesouros que não podiam ser explorados por falta de braços. Conforme salienta Trento, a partir de 1840, o café toma a dianteira e substitui o açúcar como produto de exportação: em pouco tempo, o Brasil controla o mercado

\footnotetext{
7"Cartógrafos, marinheiros, religiosos, aventureiros, escultores, soldados e botânicos italianos calcaram as terras da imensa colônia portuguesa desde o século XVI". (tradução nossa)
} 
mundial. São naturalmente os trabalhadores negros das grandes fazendas que cultivam os cafezais. Entretanto, em 1888, último dos estados civis a fazê-lo, o Brasil, através da "lei áurea", acaba com a escravidão, fechando um capítulo que durava mais de três séculos. Para o país é um grande choque, visto que agora os escravos negros não querem mais trabalhar para os antigos patrões. Para um país sempre às voltas com a falta de mão-de-obra é um verdadeiro drama.

O governo brasileiro pensa que a solução para o problema poderia ser encontrada na Itália: a matéria-prima de que o Brasil precisa é abundante em muitas regiões da Península, especialmente no Vêneto, onde as pessoas são descritas como dóceis, respeitosas, trabalhadoras e também limpas. Além disso, a chegada de imigrantes vindos da Europa poderia atender tanto à exigência de povoar os imensos estados do sul do país, quanto à "volontà di "sbiancare" una razza ritenuta troppo scura." (TRENTO, 2002, p. 3) ${ }^{8}$

Na segunda metade do século XX, o governo brasileiro anuncia, então, as vantagens da emigração. Aos emigrantes se oferecem até mesmo viagem gratuita e a promessa de um pedaço de terra para cultivar. Os camponeses italianos, miseráveis e sem outras oportunidades, na esperança de finalmente obter este pedaço de terra para trabalhar e sem se ater a detalhes, assinaram um contrato em branco, por meio do qual as autoridades brasileiras se reservaram o direito de dispor dos emigrantes de acordo com a necessidade. Conta Enzo Andriolo (apud STELLA; TETI, 2006, p. 3): "In cambio del biglietto e della promessa di un pezzo di terra da coltivare gli emigranti si obbligavano ad andare dove avesse voluto il governo e venivano inviati sovente in zone selvagge e malsane, a sostituire gli schiavi liberati."

Uma parte dos recém-chegados era enviada para os imensos, selvagens e despovoados estados do Brasil meridional (Rio Grande do Sul, Santa Catarina e Paraná), onde as condições climáticas e culturais, mais parecidas com as europeias, permitiam aos imigrantes pôr em prática os próprios conhecimentos. Mas, como afirma Angelo Trento (2002, p. 8):

\footnotetext{
8"vontade de "embranquecer" uma raça considerada muito escura". (tradução nossa)

9"Em troca da passagem e da promessa de um pedaço de terra para cultivar, os emigrantes se obrigavam a ir aonde quisesse o governo e frequentemente eram enviados para lugares selvagens e insalubres, para substituir os escravos libertos". (tradução nossa)
} 
Il processo di acquisizione della terra fu tutt'altro che facile. Gli immigranti erano trasportati, gratuitamente, dal porto di sbarco ai vari nuclei. Questi [........] erano divisi in lotti tra $i 25$ ed $i 60$ ettari, che venivano concessi esclusivamente a famiglie e dovevano essere riscattati ratealmente a partire dal secondo anno, cioè dopo aver effettuato il primo raccolto. I coloni ricevevano una casa provvisoria, nonché sussidi alimentari, attrezzi agricoli e sementi da rimborsare in seguito [....... La famiglia colonica si assumeva l'obbligo di disboscare una parte del lotto, preparare il terreno per le coltivazioni, seminare, costruire la propria abitazione e aprire strade e sentieri per delimitare $i$ confini della proprietà. ${ }^{10}$

A vida no interior das colônias não foi absolutamente fácil, sobretudo porque, terminado o entusiasmo inicial, os imigrantes perceberam as dificuldades que tinham de enfrentar, dificuldades ligadas à escassa e onerosa assistência médica, à falta de escolas, ao isolamento excessivo e à presença dos índios que "si tramutò frequentemente in scontri e nell'organizzazione di spedizioni punitive e razzie." (TRENTO, 2002, p. 8). ${ }^{11}$

Se nas áreas coloniais uma parte significativa da emigração italiana conseguiu coroar o sonho de adquirir um fundo agrícola, muito diferente foi a situação para quem foi trabalhar nas fazendas. Ali a vida era muito mais dura e não dava ao imigrante a possibilidade de economizar para poder comprar o próprio terreno. Além disso:

Il mondo della fazenda era un mondo di segregazione [.........] violenza e molestie sessuali. La volontà del proprietario o dell'amministratore era legge e non esisteva quasi libertá personale; l'assistenza sanitaria, l'istruzione e gli stessi conforti religiosi risultavano assenti o assicurati con grande parsimonia. (TRENTO, 2002, p. 11) ${ }^{12}$

A chegada de numerosos imigrantes da Península italiana permitia ao Brasil uma ampla reposição de trabalhadores. Além disso, a perspicácia dos fazendeiros ao contratar famílias de regiões diferentes dificultava as ações comuns e o

\footnotetext{
10"O processo de aquisição da terra foi tudo menos fácil. Os imigrantes eram transportados, gratuitamente, do porto de desembarque aos vários núcleos. Estes (...) eram divididos em lotes de 25 a 60 hectares, que eram concedidos exclusivamente a famílias e deviam ser resgatados em parcelas a partir do segundo ano, isto é, depois de feita a primeira colheita. Os colonos recebiam uma casa provisória, subsídios alimentares, ferramentas agrícolas e sementes que deveriam ser reembolsados em seguida. (...) A família assumia a obrigação de desmatar uma parte do lote, preparar o terreno para o cultivo, semear, construir a própria habitação e abrir estradas e caminhos para delimitar as fronteiras da propriedade". (tradução nossa)

${ }_{11}^{11}$ "se transformou frequentemente em choques e na organização de expedições punitivas e depredações". (tradução nossa)

12،O mundo da fazenda era um mundo de segregação (...) violência e molestações sexuais. A vontade do proprietário ou do administrador era lei e quase não existia liberdade pessoal; a assistência à saúde, a instrução e até mesmo o conforto religioso eram ausentes ou assegurados com grande parcimônia." (tradução nossa)
} 
isolamento das próprias plantações impedia práticas difundidas de revolta. A forma mais eficaz de protesto foi representada pelo abandono da plantação. Aqueles que decidiam migrar novamente ou procuravam outras fazendas que podiam oferecerIhes melhores condições de vida ou voltavam à pátria ou se transferiam para os centros urbanos em busca de novas ocupações. A maior parte dos exilados das fazendas engrossou a fila das populações urbanas, tanto é que desde o final dos anos 90 do século XIX, por exemplo, "San Paolo forniva l'immagine di città italiana." (TRENTO, 2002, p. 12) ${ }^{13}$

Os italianos se estabeleceram em mercados de trabalho que ofereciam uma grande gama de ocupações: não foram poucos os peninsulares que passaram a exercer funções de pedreiro, comerciante, artesão, engraxate, vendedor ambulante de jornais e amolador. A maior parte deles vivia em enormes cortiços, subdivididos em pequenos cômodos. À medida que a condição financeira melhorava, os imigrantes começavam a construir suas próprias casas, reproduzindo os modelos arquitetônicos da pátria materna e recriando uma pequena Itália em território brasileiro.

A emigração italiana no Brasil se intensificou entre 1887 e 1902. De acordo com Angelo Trento (2002, p. 5), "Nel quindicennio 1887 - 1902 giunsero in Brasile quasi 900.000 persone, ossia quasi il 60\% degli stranieri in entrata." ${ }^{14} \mathrm{O}$ Brasil se colocava em terceiro lugar no incessante fluxo da emigração italiana, atrás dos Estados Unidos e da Argentina. Depois de 1902, as chegadas reduziram-se consideravelmente, pois o governo italiano decidiu proibir a emigração subsidiada, por causa de denúncias sobre as dramáticas condições dos italianos, comparados a escravos brancos nas fazendas. Essa redução, provavelmente, se justificou também pela crise de superprodução do café, que determinou uma exacerbação das más condições de vida e de trabalho nas plantações.

Afirma Trento (2002, p. 5): "Nel ventennio tra le due guerre, le entrate diminuirono ulteriormente, mentre una leggera ripresa si registrò dopo il 1946." 15 Mais da metade desse último fluxo se deu em um clima de reposição da emigração assistida. A partir dos anos sessenta, porém, as chegadas se reduziram a poucas

\footnotetext{
13."São Paulo fornecia a imagem de cidade italiana”. (tradução nossa)

14،"Em quinze anos, entre 1887-1902, chegaram ao Brasil 900.000 pessoas, ou seja, quase $60 \%$ dos estrangeiros ingressos". (tradução nossa)

${ }^{15}$ "No período entreguerras, as chegadas diminuíram, enquanto uma leve retomada se registrou depois de 1946". (tradução nossa)
} 
centenas ao ano e corresponderam à lógica de transferência de encarregados de sociedades italianas com investimentos no Brasil ou a escolhas de vida guiadas pela curiosidade intelectual. As características sociodemográficas dos imigrantes mudaram com o tempo: enquanto até 1915 prevaleceram a mão-de-obra rural e os núcleos familiares, com taxas de alfabetização ainda baixas, a partir dos anos vinte começou a diminuir o componente feminino e camponês em favor de solteiros, artesãos, proletariado de fábrica e trabalhadores braçais. Tal caracterização profissional se acentuou no segundo pós-guerra, com a chegada de técnicos e operários especializados, enquanto crescia o nível de instrução.

Foi principalmente a região do Vêneto que forneceu os maiores contingentes de imigrantes, sobretudo antes de 1895, quando praticamente um em cada dois italianos provinha dessa região. A partir do final do século XIX, começaram a ganhar peso outras regiões, entre elas a Campânia, a Calábria e o Abruzzo. Trento (2000, p. 40) afirma que:

Entre 1878 e 1886, emigraram apenas vênetos e lombardos (especialmente para as áreas de colonização do Sul) e meridionais(dirigidos, em parte, para as fazendas, mas sobretudo, para os centros urbanos). Já entre 1887 e 1895, tem-se uma nítida maioria de setentrionais [...] enquanto o grosso da emigração meridional começará depois de 1893-95 e tornar-se-á majoritário a partir de 1898.

Cada uma dessas populações recriou, onde se estabelecia uma pequena comunidade, um pedaço da Itália em que mantinha os usos e os costumes da região de origem. Isso garantiu a preservação de muitas tradições italianas em território brasileiro e permitiu aos emigrantes atenuar, em parte, a saudade de casa. Apesar dos inúmeros problemas e das grandes humilhações que os italianos tiveram de sofrer, é verdade também que eles, nos locais em que se instalaram, contribuíram para a modernização da economia e da sociedade brasileira.

Mais de um século se passou desde a chegada das primeiras colônias de italianos em território brasileiro, mas afeto, admiração e reconhecimento em relação a esses italianos ainda estão vivos na mente de todos que reconhecem seu mérito e dedicando-Ihes seu trabalho e estudos. 


\section{A IMIGRAÇÃO ITALIANA NO PARANÁ}

Iniciado precocemente em 1816, com a colonização açoriana em Rio Negro, o estabelecimento de núcleos coloniais no Paraná desenvolveu-se lentamente. Até 1853, as colônias estabelecidas eram apenas três e os imigrantes recebidos nestes núcleos somavam 420 pessoas. Até 1864, somente duas novas colônias foram organizadas. Entretanto, desde os primeiros tempos da sua emancipação políticoadministrativa, os governantes do Paraná procuravam desenvolver uma política imigratória adaptada às condições peculiares da Província. Ao contrário de outras regiões do Império, onde a imigração se destinava a suprir a carência de mão-deobra na grande lavoura de exportação, no Paraná o problema imigratório foi desde logo colocado no sentido de criar uma agricultura de abastecimento. Analisando a situação da agricultura na Província, dizia o seu Presidente:

\footnotetext{
É para lamentar que esta Província, cujos terrenos produzem, com abundância, a mandioca, o arroz, o café, a cana, o fumo, o milho, o centeio, a cevada, o trigo e todos os gêneros alimentícios, compensando tão prodigiosamente os trabalhos do agricultor, receba da marina e por preços tão exagerados a mór parte daqueles gêneros.

Este estado de cousas porém temo que continuará, e que só quando colonos morigerados e laboriosos vierem povoar vossas terras vastas e fecundas, aparecerá a abastança dos gêneros alimentícios e abundantes sobras do consumo irão dar nova vida ao comércio de exportação de produtos agrícolas (MATTOS apud BALHANA, 1978, p. 21)
}

De acordo com esta orientação, os governantes da Província, nos anos seguintes, procuraram ativar planos de colonização baseados no estabelecimento de colônias agrícolas nos arredores de centros urbanos.

Da década de 1830 até 1860, alemães primeiro de Rio Negro, depois da colônia Dona Francisca, vieram estabelecer-se no rocio de Curitiba, sobretudo nas partes norte, noroeste e nordeste da cidade, em pequenas chácaras. Assim registrou-se um surto demográfico bastante significativo assinalado por uma tendência ascendente da população curitibana em meados do século XIX. Observando o êxito alcançado pela colonização espontânea das cercanias de Curitiba que propiciava melhorias sensíveis nas técnicas agrícolas, aumento da produção e do comércio, novos projetos foram desenvolvidos, visando colonizar intensivamente o planalto de Curitiba, o litoral e outras regiões do Paraná. A partir de 
1870, o programa foi dinamizado, principalmente na administração de Lamenha Lins, seguindo uma tendência geral observada em todo o Brasil no sentido de reativar a imigração. A intensa atividade colonizadora dos anos 70 é assinalada pelo estabelecimento de 26 novos núcleos coloniais, a maioria dos quais na região de Curitiba.

Nesta década teve início a imigração italiana no Paraná. Os governos provinciais usualmente transferiam a competência de colonizar às empresas particulares que, por meio de concessões, eram incumbidas de introduzir imigrantes em seus territórios. Com a adoção do sistema de contratos que cediam aos empresários de núcleos coloniais, além de vastas extensões de terra a baixo preço, importantes recursos financeiros para a instalação e manutenção dos colonos introduzidos, logo surgiram vários agentes do novo ramo de negócio. Como testemunha Altiva Pilatti Balhana (1978, p. 23): "Por um contrato desse gênero efetuado em 1871, entre o Governo da Província do Paraná e Savino Tripoti, foi programada a instalação de imigrantes italianos no litoral paranaense, em colônias fundadas para recebê-los."

A primeira leva de colonos chegou ao porto de Paranaguá em fevereiro de 1875 e a segunda apenas em setembro de 1876, tendo se fixado em Alexandra, colônia fundada pelo mesmo Tripoti, que escolhera este lugar quer pela sua posição favorável, quer pela proximidade do porto de Paranaguá.

Favorecido de especiais recomendações do Exmo. Ministro aos Presidentes
das províncias do Rio Grande do Sul, Santa Catarina e Paraná, percorri
todas as regiões marítimas das mesmas não deixando de observar nenhum
lugar que pela boa qualidade dos terrenos, pela facilidade das
comunicações, pelas proximidades de mercados consumidores e de um
porto de mar para a exportação, pudessem, no meu entender, assegurar a
prosperidade do futuro estabelecimento. Uma localidade que reunisse todas
essas condições, encontrei-a somente aos pés da Serra da Prata, no
Município de Paranaguá. (BALHANA, 1978, p. 23-24)

Dificuldades surgiram logo na fase inicial da instalação da colônia e, embora situada a pequena distância de Paranaguá, a colônia não progrediu. Várias causas foram apontadas para explicar o fracasso da empresa, sobretudo a insalubridade do clima. A fim de acomodar não somente aqueles que não desejavam mais permanecer em Alexandra, bem como outros que continuavam a chegar em grande número, o Governo Provincial criou, em 1877, a Colônia Nova Itália, com sede em Morretes. Como declara Alfredo Cusano apud Ferrarini (1973, p. 78),: 
O território de Morretes, situado a aproximadamente cinqüenta quilômetros de Paranaguá e por isso muito próximo do mar, está ao sopé da Serra do Mar, mas tem uma altitude que não ultrapassa os 10 metros. É, por isso mesmo, muito quente e úmido como todo o litoral do Brasil.

A experiência de Alexandra criou, porém, um clima desfavorável à colonização no litoral do Paraná. Os núcleos da Colônia Nova Itália nunca alcançaram real prosperidade. Assim, como afirma Altiva Pilatti Balhana (1978, p. 27-28):

De cerca de dois mil e quinhentos imigrantes instalados no litoral, foi bem pequeno o contingente daqueles que ali permaneceram. Os demais, por iniciativa própria, ou com auxílio oficial foram se transferindo para o planalto. Alguns se fixaram nas colônias já existentes, onde se instalaram ao lado de imigrantes de outras nacionalidades, como nas colônias Argelina, Pilarzinho, Muricy, Orleans, Inspetor Carvalho, Antonio Rebouças, Presidente Faria, Maria José, Balbino Cunha e Antonio Prado [.....] outros colonos foram localizados em colônias criadas para tal fim, como as de Antonio Chaves, atual município de Colombo, Santa Gabriela e Novo Tirol. Muitos reimigrantes adquiriram terrenos da municipalidade de Curitiba, constituindo colônias de povoamento espontâneo, como a colônia Dantas, na Água Verde [........] Outros, ainda, adquiriram terrenos de particulares, como em Santa Felicidade, Ferraia, Campo Magro, Bateis e outras. Finalmente, muitos foram os italianos que se fixaram na própria cidade de Curitiba.

Superadas as dificuldades dos primeiros contatos com o país de adoção, há consenso de que os imigrantes italianos estabelecidos no Paraná já começaram a desfrutar de condições de vida bastante favoráveis. Em relatório apresentado ao Ministro do Exterior da Itália, em 1895, Pietro Colbacchini assinalava que:

Il benessere in cui vivono, l' assoluta assenza di poveri e mendicanti, la salute fiorente che traspare dalle loro persone tarchiate e dai loro visi rotondi, tutto questo ed altrochè potrei dire, mostra abbastanza che il Paraná è il paese più proprio alla prosperità dei nostri emigrati italiani (apud BALHANA, 1978, p. 28). ${ }^{16}$

\footnotetext{
16“O bem-estar em que vivem, a absoluta ausência de pobres e mendigos, a saúde florescente que transparece de suas pessoas corpulentas e de seus rostos redondos mostram bem que o Paraná certamente é o lugar mais apropriado para a prosperidade dos nossos emigrantes italianos." (tradução nossa)
} 


\subsection{A SEGUNDA IMIGRAÇÃO}

No decorrer dos anos seguintes, outros italianos, procedentes sobretudo das regiões setentrionais da Itália, elegeram o Paraná e Curitiba como sua nova pátria, valendo-se de relatos daqueles que aqui já viviam. Essa onda imigratória foi constante até o final da Primeira Grande Guerra Mundial, evento que marcou o bloqueio deste fenômeno. Nos anos entre a Primeira e a Segunda Guerras, foram poucos os que chegaram em solo paranaense em virtude das restrições impostas pelo regime fascista. Tratava-se, sobretudo, de grupos de pessoas que fugiam da guerra por vários motivos. Uma notável retomada do processo imigratório verificouse logo após o final do Segundo Grande Conflito, momento em que a ponte entre Itália e Brasil foi reaberta, através de um acordo bilateral que previa três tipos de imigração: individual (na base de atos de chamada e de ofertas de trabalho), de grupos e cooperativas (sobretudo de colonização agrícola) e dirigida. A partir dessa reabertura, dá-se início ao que chamamos de segunda grande imigração italiana em território paranaense em geral e especificamente na cidade de Curitiba.

Inicialmente será traçado um perfil deste imigrante: qual a sua procedência, formação e quais os fatores que motivaram sua chegada. Como já aconteceu no primeiro grande fluxo imigratório, a maior parte dos que chegaram a Curitiba após o término da Segunda Guerra eram oriundos das regiões do Vêneto e do Trentino, porém, diferentemente daquela, nesta nova etapa, o perfil individual era muito diferente. Enquanto na primeira imigração era visível a figura do "contadino" que tinha como atribuição principal a colonização do estado através de terras recebidas do Governo, na segunda fase imigratória este indivíduo já possuía uma qualificação técnica que ajudaria, com seus conhecimentos, no desenvolvimento de uma cidade ainda em fase de construção. Eram, portanto, visíveis as diferenças tanto em nível cultural e social quanto no que diz respeito a um preparo maior para o desenvolvimento de atividades ligadas menos à agricultura e mais ao mundo da industrialização.

A partir dessas considerações e vendo a imigração italiana como um "fenômeno único", pode-se avaliar a importância da figura do imigrante para o desenvolvimento do estado do Paraná. Ou seja, embora de forma diferente, tanto o primeiro quanto o segundo imigrante eram importantes dentro do contexto de 
formação de um estado novo e de uma cidade que começava a dar seus primeiros passos na direção de sua auto-afirmação em termos de desenvolvimento. Curitiba estava, nesse período, vivendo um processo de transformação: de cidade eminentemente agrícola necessitava incrementar outros setores como, por exemplo, comércio, indústria e transportes. Ao mesmo tempo, como afirma Angelo Trento (2000, p. 405): "O fim do conflito mundial e a difícil tarefa da reconstrução tornaram novamente atual, para os italianos, o caminho da emigração como solução para os problemas criados pela escassez de trabalho e de capitais."

Ou seja, mais uma vez, como ocorrera vários anos antes, o italiano aparece como solução para suprir as necessidades existentes em Curitiba, assim como o Paraná - e sua capital em particular - representa para o italiano a oportunidade que ele esperava após os acontecimentos da Segunda Guerra Mundial.

Mesmo não existindo uma literatura específica que trate do processo imigratório do pós-guerra - já que, como dito anteriormente, os estudos sobre a presença de italianos no Paraná e na sua capital restringem-se à imigração ocorrida entre o final do século XIX e o começo do século XX - as informações dadas a respeito desta segunda onda imigratória são o resultado do que se ouviu durante as entrevistas efetuadas para este trabalho. 


\section{SITUACÃO LINGUÍSTICA DA ITÁLIA NA ÉPOCA DA GRANDE EMIGRAÇÃO}

Algumas décadas depois da unificação italiana, o Estado teve de combater as limitações impostas pela condição dos próprios habitantes: grandes massas iletradas em contraposição a uma restrita elite de homens cultos. O analfabetismo e o uso do dialeto nativo se opunham à difusão do toscano fiorentino, oposição esta reforçada pela escassez de meios e de infra-estrutura escolar. A situação melhorou progressivamente, graças a algumas reformas e à obra política de organização do Estado: redução do índice de analfabetismo e aumento do acesso da população ao estudo. Estes fenômenos foram acompanhados de dinâmicas internas da população, como o processo de migração para os grandes centros e os grandes fluxos migratórios para o exterior, mas também em direção a cidades mais desenvolvidas no próprio Estado nacional. Esses últimos dois fenômenos contribuíram para a difusão do toscano florentino como língua nacional e para o desaparecimento dos dialetos, que foram relegados a língua não oficial.

\subsection{PROBLEMAS CULTURAIS E LINGUÍSTICOS NA ITÁLIA PÓS- UNIFICAÇÃO}

Quando a Itália foi unificada, ainda eram pouquíssimos aqueles que tinham condições de usar a língua nacional. Segundo Storia linguistica dell'Italia unita de Tullio de Mauro (2002, p. 36-37), o censo de 1861 mostrou que o analfabetismo chegava a 78\%: no Piemonte e na Lombardia, era de, no mínimo, 50\%; e, nas ilhas, de $90 \%$. Mas muitos dos $22 \%$ restantes eram capazes apenas de escrever o próprio nome e de decifrar um pouco as letras de forma.

Excetuando a Toscana e Roma, pode-se calcular que somente 0,8\% da população italiana era realmente capaz de falar e escrever em italiano (aproximadamente 160.000 pessoas de um total de 20 milhões); considerando a Toscana e Roma, cujos dialetos locais eram, em relação à estrutura fonológica, 
morfológica e lexical, próximos à língua comum, chegava-se a 2,5\%, o equivalente a cerca de 600.000 pessoas.

Isso significa que a língua de uso cotidiano, para a grande maioria da população italiana, no momento da unificação, ainda era o dialeto local. O problema da unificação linguística, que já tinha sido identificado pelos intelectuais da primeira metade do século XIX, configurava-se, pois, como um dos mais urgentes. De fato, no novo Estado, a unificação política e econômica exigia contínuas e intensas trocas entre todas as regiões, e uma língua comum que fosse verdadeiramente usada por toda a população era uma exigência imprescindível.

O problema, porém, não era apenas como divulgar a língua nacional, mas sim definir o modelo de língua que se difundiria. De fato, sendo praticamente apenas uma língua literária, o italiano era como uma língua morta, pobre e incerta, como muito bem havia observado Manzoni desde 1821: ela não oferecia todos os termos e sentidos que serviam à comunicação em geral, nos escritórios, nas escolas, nos mercados, nas oficinas, nos laboratórios científicos etc., e não remetia a um código seguro, consagrado pelo uso, que garantisse a compreensão recíproca. A autoridade de um intelectual como Manzoni, graças também ao exemplo concreto do seu livro Promessi Sposi, impôs a sua solução que consistia na adoção da língua falada pelos florentinos cultos, difundida por meio de um grupo de mestres treinados no uso do florentino e através de um dicionário.

De acordo com Laura e Giulio Lepschy (1993, p. 20): "Manzoni non voleva che fosse la letteratura a decidere quale doveva essere la lingua nazionale; voleva invece che la letteratura adottasse la lingua che meglio conveniva alle condizioni del paese." 17

Os escritores não deviam, pois, tentar impor ao país a língua retórica e arcaica da literatura italiana do passado; ao contrário, deviam usar um idioma vivo, que pudesse se tornar língua nacional, escrita e falada. Essa solução encontrou apoio na classe política do Estado unitário, e efetivamente nas escolas de ensino fundamental se tentou impor o modelo florentino, combatendo duramente o uso dos dialetos. A solução manzoniana revelou-se, porém, abstrata e impraticável. Era uma contradição querer impor o uso de uma língua viva por meio do estudo e das regras

\footnotetext{
17"Manzoni não queria que a literatura decidisse qual deveria ser a língua nacional; queria, ao contrário, que a literatura adotasse a língua que melhor convinha às condições do país." (tradução nossa)
} 
de um dicionário. Uma língua verdadeiramente viva não podia ser imposta do alto, mas somente podia nascer do uso concreto dos falantes e pressupunha a participação em momentos de vida coletiva, trabalho, estudo, lazer. Era esta a objeção que um grande linguista, Graziadio Isaia Ascoli, fazia à alternativa de Manzoni. No prefácio do Archivio glottologico italiano de 1873, ele afirmava que uma verdadeira língua nacional somente poderia nascer da circulação das ideias em uma sociedade civil viva e rica de trocas.

Em teoria, a escola se apresentava como o instrumento mais adequado para a difusão da língua comum. As leis Casati (1859) e Coppino (1877) haviam determinado o princípio da obrigatoriedade da instrução básica, prevendo pesadas sanções aos pais que não mandassem os filhos às escolas municipais se não lhes tivessem providenciado uma outra forma de instrução. As estruturas de ensino, porém, eram frequentemente deficientes, o pessoal inadequado e muitas crianças, especialmente no sul, escapavam à obrigatoriedade, porque estavam ocupadas nos trabalhos do campo e em outras atividades. Além disso, na situação de profundo atraso das massas populares, não se compreendia a importância da instrução e não se percebia a sua necessidade. Mesmo as classes proprietárias às vezes não favoreciam a educação dos camponeses com medo de que ela pudesse torná-los menos dóceis.

Portanto, a difusão do italiano foi um processo lento, gradual e difícil. Juntamente com o aumento da instrução (em 1901, o percentual de analfabetismo havia caído para 48,7\%), outros fatores sociais contribuíram para a afirmação da língua nacional: o alistamento obrigatório que determinou o deslocamento e a convivência em quartéis distantes da região de origem de milhares de jovens provenientes de lugares diferentes, que para se comunicarem entre si e com os seus superiores eram obrigados a falar italiano; a ampliação das trocas no mercado nacional que, para negócios de diferentes naturezas, obrigava pessoas de várias regiões a se comunicarem entre si; o crescimento da burocracia, com a qual mais cedo ou mais tarde todos teriam de lidar; a migração para o exterior, que colocava os analfabetos em contato com sociedades mais evoluídas. Quando veio a industrialização, tiveram início as migrações internas, que fizeram com que pessoas das mais diversas origens regionais se misturassem e, consequentemente, descobrissem que era indispensável ter um instrumento de comunicação comum. 
A difusão dos jornais e da imprensa periódica também teve influência nesse processo, ao menos junto aos estratos alfabetizados, que estavam crescendo. No século $X X$, um poderoso fator de unificação linguística seria a mídia de grande abrangência como o rádio, o cinema e, em anos mais recentes, a televisão. Estes fenômenos tiveram consequências tanto na situação cultural quanto na linguística. $A$ tendência geral desses eventos foi, sem dúvida, a de enfraquecer os dialetos e de reforçar o uso do italiano.

Fica evidente, portanto, que o processo de unificação linguística, assim como o de unificação nacional, foi longo e doloroso. Foi necessário quase um século para completá-lo. Aliás, ainda hoje, em muitas áreas da Itália, a língua italiana é usada nas ocasiões "oficiais", enquanto a língua preferida em âmbito familiar é o dialeto. Tal dicotomia entre língua oficial e dialetos marca profundamente a cultura italiana desde o período posterior à unificação nacional até os dias de hoje.

Se a língua representa a identidade de um povo, então é fácil entender as dificuldades que o italiano teve de enfrentar para se impor como língua oficial do Estado. Graziadio Izaia Ascoli apud Laura Lepschy e Giulio Lepschy (1993, p. 22) afirmava que: "La situazione linguistica di un paese non si cambia con un decreto, 0 dando alla gente un dizionario del dialetto che si propone come standard nazionale. La formazione di una lingua nazionale è un fenomeno storico complesso che dipende da forze sociali e culturali."

Foram necessárias muitas décadas, muitas mudanças internas e duas grandes guerras para se chegar à situação atual, uma situação que seguramente vê a língua italiana como língua não apenas escrita mas também falada, mas que deve conviver ainda com muitos dialetos e muitas variantes regionais.

\subsection{A LÍNGUA DO EMIGRANTE}

Segundo resultados de pesquisas sociolinguísticas feitas em diversas áreas por estudiosos como Alberto Sobrero, Massimo Vedovelli, Tullio de Mauro e Gaetano

\footnotetext{
18“"A situação linguística de um país não se muda com um decreto ou dando às pessoas um dicionário do dialeto que se propõe como padrão nacional. A formação de uma língua nacional é um fenômeno histórico complexo que depende de forças sociais e culturais." (tradução nossa)
} 
Berruto, a emigração foi um grande fator de italianização. De fato, além de reduzir o número dos analfabetos na pátria, ela conscientizou tanto aqueles que permaneceram em casa quanto aqueles que voltavam com ideias mais avançadas acerca da importância da instrução e da posse da língua nacional como instrumento para melhorar as próprias condições.

"Se prima l'esercizio dell'occhio e della mano sembrava ginnastica inutile", escrevia em 1911 o demógrafo Francesco Coletti apud Luca Serianni (1990, p. 25) relatando as conclusões de uma sondagem relativa ao Abruzzo e ao Molise, mas que facilmente podem ser generalizadas -, "ora appare fecondo e santo. Chi da giovane non ha appreso, ovvero ha dimenticato, torna a scuola [....] ed il contadino paga mensilmente il maestro." 19

Antes de ser apresentado um quadro geral sobre a condição linguística em que se encontravam os italianos na época de sua partida, é preciso que sejam feitas algumas considerações gerais sobre a língua usada por quem vive no exterior há muito tempo.

A partir do que foi lido e analisado, pode-se afirmar que o processo de dessemantização e de redução da bagagem lexical é um fenômeno determinante na língua italiana falada por quem vive no exterior. Isto se deve à falta de contato com a realidade linguística nacional, à falta de reforço ou de renovação necessários para que as estruturas lingüísticas sejam usadas de modo espontâneo e automático, ao contato com outros códigos linguísticos e à contínua passagem de uma língua para a outra. De acordo com Vincenzo Lo Cascio (1994) apud De Mauro (1994, p. 64): "La prima cosa che succede nel momento della perdita della propria lingua è quella di perdere la capacità di usare tutta la batteria di sinonimie. Nell'albero gerarchico rimangono le parole presenti nei nodi più alti, cioè quelle semanticamente meno ricche. ${ }^{, 20}$

Naturalmente para analisar adequadamente a língua falada pelos italianos no exterior seria necessário fazer uma distinção com base na geração, na área geográfica de imigração, no tipo de língua com a qual se tem contato, no momento da emigração, na competência da língua nacional e no grau de dialetofonia no

\footnotetext{
${ }^{19}$ "Se antes o exercício do olhar e das mãos parecia ginástica inútil, agora parece fecundo e santo. Quem na juventude não aprendeu ou na verdade esqueceu, volta à escola [...] e o camponês paga mensalmente o professor." (tradução nossa)

20"No momento da perda da própria língua, perde-se primeiro a capacidade de usar toda a gama de sinônimos. Na árvore hierárquica permanecem as palavras presentes nos galhos mais altos, isto é, aquelas semanticamente menos ricas." (tradução nossa)
} 
momento da partida. Obviamente, essa análise nos permitiria entender melhor a presença ou a ausência de alguns fenômenos, além da manutenção ou da perda da língua materna.

Lo Cascio apud De Mauro (1994, p. 64) afirma ainda:

\begin{abstract}
Il parlato degli emigranti italiani, la maggioranza dei quali ha lasciato l'Italia nel momento in cui la dialettofonia era alta, è fatto di residui di italiano e di residui di dialetto. La competenza dellitaliano non ha subito una vera e propria evoluzione, si è invece impoverita al massimo, ridotta quasi al livello soglia, e permeata di molti forestierismi, elementi lessicali integrati nel discorso quotidiano, caratterizzato da meccanismi intonativi non autoctoni ma provenienti dalle lingue con cui gli italiani all'estero sono a contatto, da spostamenti di accenti nella struttura prosodica a causa di prestiti dalla L2, da calchi sintattici, da cambiamenti nell'ordine delle parole... ${ }^{21}$
\end{abstract}

Provavelmente foi isso que aconteceu aos emigrantes italianos que chegaram ao Brasil ao longo de um século, ou seja, do final dos anos 70 do século XIX até o início dos anos 70 do século XX. Obviamente estes fenômenos têm graus diferentes de acordo com a situação: momento da partida, pertencimento a uma comunidade e nível de cultura, por exemplo.

Serão vistas a seguir quais eram as condições linguísticas em que se encontravam os emigrantes na época de sua partida, isto é, que língua falavam e de que forma ela foi mantida com o passar dos anos e ao sofrer contínuas interferências de uma segunda língua; posteriormente, enfim, serão apresentadas quais as diferenças lingüísticas existentes entre o primeiro e o segundo emigrante.

Para poder reconstruir um quadro geral verdadeiro sobre o tema, são necessários alguns esclarecimentos: primeiramente, serão abordados os emigrantes italianos que chegaram ao estado do Paraná e à sua capital, Curitiba. Além disso, serão chamados de primeiros emigrantes todos aqueles que deixaram a Itália logo depois da unificação nacional, lembrando-se que a primeira onda migratória propriamente dita foi a que aconteceu entre 1875 e os anos anteriores à explosão da Primeira Guerra Mundial, como foi afirmado anteriormente neste trabalho. O termo segundo emigrante será usado para referir-se a quem deixou o país no período que

\footnotetext{
21 "A fala dos emigrantes italianos, a maioria dos quais deixou a Itália num momento em que a dialetofonia era alta, é feita de resíduos do italiano e de resíduos de dialeto. A competência do italiano não sofreu propriamente uma evolução, ao contrário, empobreceu-se ao máximo, sendo reduzida quase ao nível básico, e permeada de muitos estrangeirismos, elementos lexicais integrados ao discurso cotidiano, caracterizado por mecanismos de entonação não autóctones mas provenientes das línguas com as quais os italianos têm contato no exterior, dos deslocamentos dos acentos na estrutura prosódica em razão de empréstimos da $L 2$, de decalques sintáticos, de mudanças na ordem das palavras..." (tradução nossa)
} 
vai do final do Segundo Conflito Mundial até o início dos anos 70. Tal esclarecimento é indispensável em vista das diferentes condições sociais, econômicas e culturais que vigoravam no país nestes dois períodos e também da diferente extração sociocultural dos dois emigrantes. De fato, os primeiros eram em sua maioria camponeses, pobres e analfabetos, à procura de terra para cultivar; os segundos já faziam parte de uma classe trabalhadora mais especializada (técnicos, comerciantes, artesãos), que tinha estudado e conseguido um diploma e que migrava não somente por necessidade mas também por desilusão com os acontecimentos que sucederam a guerra ou para ter uma experiência de vida em um outro país.

A situação linguística quando da partida dos primeiros emigrantes previa 0 uso do dialeto nativo como língua materna (L1). A maior parte deles nunca tinha falado italiano nem frequentado a escola, apesar de a lei Coppino, promulgada em julho de 1877, tornar obrigatória a frequência à escola, ainda que limitada aos primeiros dois anos. Nas diferentes comunidades italianas que se estabeleceram no exterior após a unificação nacional se falava, pois, quase exclusivamente dialeto. Isso aconteceu também com a comunidade italiana que se fixou na capital do Paraná, Curitiba. Das memórias de Giuseppe Martini, um dos pioneiros da já citada colônia de Santa Felicidade, apreende-se que a língua falada em casa era o dialeto vêneto junto com a língua portuguesa, que começava a fazer o papel de segunda língua (L2). Portanto, no momento em que chegaram ao país de adoção, os emigrantes tiveram de aprender rapidamente a língua desse país para poder dialogar com os proprietários dos terrenos, receber o pagamento, obter os documentos necessários para se tratar ou os bens de primeira necessidade. $O$ dialeto sobrevivia no interior das comunidades de italianos que estavam próximas, era usado como registro informal e representava os vínculos de solidariedade entre os indivíduos.

Os segundos emigrantes, que constituem a maioria dos imigrantes italianos ainda vivos, além do dialeto que falavam sobretudo em casa e em determinadas situações, já eram capazes de usar a língua italiana que haviam estudado na escola e com a qual começavam a se familiarizar. Quando chegaram aos países de destino, continuaram a usar, durante um certo período, o dialeto enquanto cada vez mais substituíam o italiano pelo português, que se tornou para eles a nova língua materna e que começaram a ensinar para os seus filhos. O conhecimento e o uso da nova 
língua logo se impuseram como condição necessária não apenas para a plena participação na vida civil, mas também, como já acontecera com os pioneiros, para encontrar trabalho e sobreviver dignamente.

Além disso, é necessário ressaltar que os segundos, diferentemente dos primeiros, não se dirigiram às colônias, onde havia outros membros da mesma comunidade que falavam a mesma língua, mas se fixaram em diversos bairros da cidade, chegando a confundir-se com os nativos e sendo, assim, obrigados a se expressar na língua portuguesa.

De acordo com o que se depreende das entrevistas feitas com os emigrantes italianos que chegaram à capital paranaense entre o fim da Segunda Guerra Mundial e o início dos anos 70, pode-se afirmar que a sua língua oral, em relação às palavras de uso mais frequente, é similar àquela de seus conterrâneos residentes na Itália. Naturalmente, não tendo acompanhado a evolução da língua materna, é preciso pesquisar as diferenças, por exemplo, nos neologismos e no número e tipo de palavras menos frequentes, na desenvoltura, na prolixidade e nas interferências. A língua oral desses emigrantes é, antes de tudo, coloquial, familiar e informal: faltamIhe a elegância e a variedade estilística característica de quem ainda vive na Itália. Apesar disso, há, por parte deles, a vontade de não esquecer uma língua que faz parte de seu passado e de sua história. Para eles, o italiano é a língua da memória, das recordações, do contato com uma pátria distante geograficamente, mas sempre presente nos seus corações. 


\section{O ITALIANO E SUAS TRANSFORMAÇÕES. TRANSCRIÇÃO E ANÁLISE DAS ENTREVISTAS EFETUADAS}

O corpus deste trabalho é constituído de seis entrevistas efetuadas com imigrantes italianos residentes na cidade de Curitiba, capital do Estado do Paraná, que chegaram aqui no período conhecido como pós-guerra, aproximadamente entre 1949 e 1970. Em seguida, as entrevistas serão transcritas e analisadas individualmente.

Efetuar a transcrição de entrevistas não é uma tarefa simples, pois demanda muitas horas de empenho, ouvindo atentamente e, em alguns casos, várias vezes o mesmo trecho para poder compreendê-lo da melhor forma possível. Algumas vezes, mesmo ouvindo repetidamente uma palavra, não foi possível decifrá-la. Nestes casos, para não alterar a essência da frase, ela foi marcada com um sinal prédefinido. Um dos problemas mais freqüentes, durante a gravação era que o entrevistado alterava repentinamente tanto a entonação quanto a velocidade da voz. Estes fenômenos são comuns e perceptíveis em quase todas as entrevistas, quem sabe pelo acúmulo de sentimentos e emoção experimentados quando da proposição do assunto.

Para a transcrição dos testemunhos foram utilizados os procedimentos do Projeto Norma Urbana Culta - NURC - que é de âmbito nacional e internacional e tem como objetivo o estudo da linguagem culta falada no Brasil. Para tanto, utilizaram-se suas normas de transcrição, embora alguma modificação tivesse de ser realizada.

Pela análise das entrevistas efetuadas e levando em consideração o efeito causado pelo longo período vivido em contato com uma segunda língua, é objetivo deste trabalho detectar as interferências do português no repertório lexical da língua italiana falada pelo imigrante. Espera-se, também, determinar as causas que foram relevantes para a alteração na língua italiana falada. 


\subsection{METODOLOGIA DAS ENTREVISTAS}

Localizar o imigrante italiano do período do pós-guerra foi um grande desafio. Somente com a ajuda de outras pessoas conhecidas é que estes encontros foram possíveis. Foi impossível encontrá-los dentro dos núcleos italianos aqui existentes, e este fato que chama muito a atenção, pois todos os colaboradores deste trabalho moram longe uns dos outros e também dos bairros tidos como italianos em Curitiba. Depois de ter feito este primeiro contato e de o entrevistado aceitar colaborar com o trabalho, foi-lhe informado antecipadamente como a entrevista seria conduzida e quais os objetivos concretos.

Para tanto, foi criado um questionário direcionado, composto de 24 perguntas (conforme mostra o anexo 1) que tratava não só dos motivos da saída da Itália como, por exemplo, da impressão quando da chegada ao destino. Essa sequência de perguntas só foi quebrada quando o entrevistado, levado por um sentimento ou um outro fator qualquer, tomava alguma variante que foi devidamente respeitada pelo entrevistador. Tudo isso para que não houvesse perda de espontaneidade por parte do entrevistado.

Para deixar os entrevistados mais à vontade, as entrevistas foram realizadas nas suas casas, tomando-se o devido cuidado para que não houvesse interferência de nenhuma ordem. Mesmo assim, em alguns casos, as interrupções foram inevitáveis.

Em média cada entrevista teve a duração aproximada de 40 minutos, enquanto para cada transcrição não se levou mais de 10 minutos. Os trechos selecionados foram os que pareciam apresentar maior possibilidade de análise.

Cada entrevista será precedida de algumas informações gerais sobre o entrevistado, como, por exemplo: data e lugar de nascimento, ano de partida da Itália, grau de escolaridade e profissão. Tudo isso para que se desenhe um quadro claro de cada uma das entrevistas. Após a transcrição dos trechos selecionados, será feita uma análise linguístico-lexical, com o objetivo de destacar a manutenção ou a perda de desempenho da língua materna, ou ainda a eventual transformação causada por vários motivos, sobretudo os muitos anos de contato direto com a 
língua portuguesa e o uso cotidiano de um outro código linguístico. Serão observados então os efeitos da exposição prolongada a uma L2.

Concluída a análise de cada uma das entrevistas, será apresentada uma tabela composta pelos principais fenômenos encontrados. Cada uma das tabelas será elaborada de modo a oferecer um quadro claro daquilo que foi detectado durante a transcrição.

\subsection{CARACTERÍSTICAS DOS ENTREVISTADOS}

Todos os entrevistados têm como língua materna o italiano, são provenientes da região norte da Itália e estão na terceira idade. Quatro deles são do sexo masculino e dois do feminino. Todos vivem no Brasil, na cidade de Curitiba, há muito tempo. Alguns deles chegaram ao país logo após o fim da Segunda Grande Guerra Mundial, ou seja, no início dos anos cinquenta; outros para cá vieram na década de sessenta. Portanto, todos construíram as suas histórias em território brasileiro, seja do ponto de vista profissional, seja do ponto de vista pessoal, com a formação de um núcleo familiar, visto que quase todos se casaram com brasileiros.

Outra característica comum entre eles é o fato de serem aposentados. Entretanto, alguns continuam desenvolvendo algum tipo de atividade profissional. Todos eles usam a língua portuguesa no cotidiano, dentro e fora de suas casas, tanto que os filhos aqui gerados foram criados dentro deste código linguístico. Talvez por isso foi possível notar, por parte deles, um ótimo desempenho na L2 falada.

Um fato que merece destaque é que dois dos entrevistados desenvolvem suas atividades profissionais ligadas diretamente à língua italiana, como professores em uma escola particular. Os outros apenas em ocasiões especiais conseguem manter diálogos com outros falantes nativos, como, por exemplo, em encontros sociais diversos e em cursos de língua ou cultura italiana.

Outro ponto em comum a salientar é que nenhum deles, quando da chegada a Curitiba, instalou-se em qualquer um dos vários núcleos italianos ali existentes, núcleos estes formados quando da primeira grande imigração, ocorrida entre o final do século XIX e o início do século XX. Ao contrário, foram se instalando em 
diferentes bairros da cidade, misturando-se assim com os curitibanos, o que possibilitou uma maior integração e que facilitou e acelerou o processo de aprendizagem da língua portuguesa falada.

A demonstração espontânea de um grande amor pela Pátria, seja entre os que chegaram ao Brasil aos vinte e poucos anos, quer entre aqueles que chegaram quando eram crianças, é outro fato que chamou a atenção durante as entrevistas, mais claramente ao final delas.

Finalmente, alguns dos entrevistados tiveram a oportunidade de retornar à Itália algumas vezes e assim acompanhar de perto a evolução gradual do seu País. Os outros testemunharam essa evolução de longe, mesmo assim com bastante interesse, já que todos, sem exceção, lá deixaram muitos de seus familiares.

\subsection{NORMAS PARA TRANSCRIÇÃO}

Como já frisamos anteriormente, para a transcrição dos testemunhos foram utilizados procedimentos do Projeto Norma Urbana Culta - NURC -, que é de âmbito nacional e internacional e tem como objetivo o estudo da linguagem culta falada no Brasil. Para tanto, utilizaram-se suas normas de transcrição, embora alguma modificação tivesse de ser realizada. Por exemplo, em lugar do sinal destinado ao significado de incompreensão ( ), usado pelos pesquisadores do NURC, preferiuse usar um outro símbolo, melhor definido, ou seja: (incompreensível). Além disso, no lugar do sinal indicativo de uma pausa ... preferiu-se utilizar o símbolo (+). À exceção desses casos, de forma geral, respeitaram-se as normas de transcrição do Projeto NURC. A seguir apresentamos a tabela que resume as normas utilizadas e que permite uma maior compreensão do trecho transcrito. 


\begin{tabular}{|c|c|c|}
\hline \multicolumn{3}{|c|}{ Tabela 4.1. NORMAS PARA TRANSCRIÇÃO } \\
\hline Ocorrências & Sinais & Exemplificação \\
\hline $\begin{array}{l}\text { Incompreensão de } \\
\text { palavras ou } \\
\text { segmentos }\end{array}$ & (incomprensibile) & $\begin{array}{l}\text { Beh sai quando si è bambini } \\
\text { (incomprensibile) son tutti } \\
\text { belli }\end{array}$ \\
\hline $\begin{array}{l}\text { Hipótese do que se } \\
\text { ouviu }\end{array}$ & (hipótese) & $\begin{array}{l}\text { Ho fatto la finale con una } \\
\text { argentina (incomprensibile) } \\
\text { (non me la dimenticherò) }\end{array}$ \\
\hline Truncamento & I & $\begin{array}{l}\text { Lei ha fatto la richiesta per / } \\
\text { la prima volta io / e alcuni } \\
\text { anni fa / prima ancora di } \\
\text { iniziare la guerra }\end{array}$ \\
\hline Entonação enfática & maiúscula & $\begin{array}{l}\text { Mio papà era muratore però } \\
\text { non c'era LAVORO }\end{array}$ \\
\hline $\begin{array}{l}\text { Prolongamento de } \\
\text { vogais e consoantes }\end{array}$ & $\begin{array}{l}\text { : podendo aumentar } \\
\text { para :: ou mais }\end{array}$ & $\begin{array}{l}\mathrm{E}:: \text { mia mamma era una } \\
\text { donna semplice }\end{array}$ \\
\hline Interrogação & $?$ & $\begin{array}{l}\text { Come mai mettono la roba } \\
\text { ad asciugare per terra? }\end{array}$ \\
\hline Qualquer pausa & $\begin{array}{c}\text { (+) podendo } \\
\text { aumentar para }(++) \\
\text { ou mais }\end{array}$ & $\begin{array}{l}\text { Mia nonna e due zii fratelli di } \\
\text { mio papà stavano già qui }(+) \\
\text { allora lei ha fatto la richiesta }\end{array}$ \\
\hline $\begin{array}{l}\text { Comentários } \\
\text { descritivos do } \\
\text { transcritor }\end{array}$ & ((minúscula) $)$ & $\begin{array}{l}\text { Coccodrilli per la strada gli } \\
\text { indios }(+) \text { come si vedeva } \\
\text { nei film }((\text { risate })) \text { no? }\end{array}$ \\
\hline $\begin{array}{l}\text { Superposição, } \\
\text { simultaneidade de } \\
\text { vozes }\end{array}$ & $\begin{array}{l}\text { Ligando } \\
\text { [ } \\
\text { as linhas }\end{array}$ & $\begin{array}{l}\text { Due famiglie } \\
\text { due famiglie }\end{array}$ \\
\hline $\begin{array}{l}\text { Citações literais ou } \\
\text { leituras de textos } \\
\text { durante a gravação }\end{array}$ & & $\begin{array}{l}\text { La cosa che mi ha chiamato } \\
\text { molta ma molta attenzione era } \\
\text { la roba stesa per terra dico } \\
\text { "come mai mettono ad } \\
\text { asciugare la roba per terra?" }\end{array}$ \\
\hline
\end{tabular}




\section{OBSERVAÇÕES:}

1) Iniciais maiúsculas: somente para nomes próprios.

2) Fáticos: ah, eh, neh, beh.

3) Números: por extenso.

4) Não se indica o ponto de exclamação.

5) Não se anota o cadenciamento da frase.

6) Não se utilizam sinais típicos da língua escrita como: ponto-e-vírgula, pontofinal, dois-pontos, vírgula. 


\section{ENTREVISTA N¹}

Sexo: $\quad$ feminino

Ano de nascimento: $\quad 1939$

Lugar de nascimento: Cessalto, província de Treviso

Partida da Itália: $\quad$ 1950, aos 11 anos

Profissão: $\quad$ aposentada

Doc che ricordi (+) ha del suo luogo di nascita?

Inf beh sai quando si è bambini (incomprensibile) son tutti belli però c'era una grande difficoltà del dopoguerra come è stato in Italia che tutti lo sanno (++) e:: mia mamma era una donna semplice una contadina mio papà era muratore però non c'era LAVORO (++) e: e così (++)

Doc avete deciso di partire

Inf perché mia nonna e due zii fratelli di mio papà stavano già qui (+) allora lei ha fatto la richiesta (+) per / la prima volta (+) io / e alcuni anni fa / prima ancora di iniziare la guerra (incomprensibile) dopo invece è scoppiata la guerra i porti si son chiusi e non (+) insomma siamo arrivati qui $(++)$ e:: nel cinquantuno il tre di gennaio del cinquantuno

Doc del cinquantuno

Inf cioè (+) il viaggio è durato un mese pressappoco non mi ricordo bene la data (+) do / tutto il mese di dicembre siamo arrivati proprio

Doc tutta la famiglia è arrivata qui?

Inf due famigl 
Doc due famiglie

Inf il fratello di mio papà eravamo in ventidue persone

Doc ventidue persone

Inf tra le due famiglie

Doc quando le hanno detto che: $(+)$ che sareste partiti per venire in questo nuovo paese $(+)$ come gliel'hanno detto?

Inf eh:: insomma la NONNA la nonna che ci mandava notizie che il Brasile era meraviglioso che era questo quel / (+) però a me / l'immagine che un bambino fa di Brasile di: (+) dei: coccodrilli per la strada gli indios (+) come si vedeva nei film ((risate)) no? E quell'idea era un'idea che si faceva a quei tempi non è che sapevamo TANTO come oggi si sa tutto neh? (+) a quei tempi invece: (+) però era un'illusione era una un mondo nuovo quasi un altro pianeta quasi $(+)$ a quei tempi $(+)$ eravamo contentissimi

Doc non eravate dispiaciuti di lasciare il paese

Inf no no (+) no per niente (+)

Doc gli amici?

Inf no per niente $(+)$ cioè conoscere i cugini che avevamo qua (+) la preoccupazione di parlare un'altra lingua $(+)$ no $(+)$ per me per ese / era stato bellissimo $(++)$ anche se dopo quando siamo ((risate)) arrivati (+) abbiamo avuto qualche delusione ma $(+++)$

Doc in generale eravate contenti

Inf si perché: mio papà poi era lui era molto arrabbiato con l'Italia perché aveva perso due o tre fratelli nella prima guerra (+) allora diceva che l'Italia era sua debitora che aveva (+) ammazzato i suo / i suoi fratelli che lui non sarebbe mai più ritornato $(++)$ era $(+)$ molto $(+)$ arrabbiato con la patria $(+)$ è arrivato qui era un paradiso (+) secondo lui: era una meraviglia 
Doc e il viaggio ti ricordi qualcosa del viaggio?

Inf si:: non molto perché $(+)$ cioè GIOCAVAMO li: mi ricordo che: un giorno il mare era troppo $(++)$ passavamo il $(+)$ il golfo Leone la non lo so almeno $(++)$ e: (incomprensibile) stavamo molto bene insomma ((risate)) sai il mare $(+)$ ma comunque $(+)$ eh c'era tanta gente c'erano anche degli arabi nella nave e loro facevano quelle / cantavano facevano quelle insalatone di CIPOLLA la mangiavano con le mani e io ero spaventata perché era una cosa diversa no?

Doc e la nave è partita $(+)$ da Genova?

Inf a Genova si (+) e si chiamava Santa Cruz e anche quella faceva l'ultimo viaggio perché era molto rovinata che ormai era $(++)$ cioè non $(+)$ non tornava più a viaggiare era l'ultimo

Doc e dove siete arrivati ((nome)) siete arrivati anche voi a Santos?

Inf no no noi siamo sbarcati a Rio

Doc a Rio

Inf sì e e siamo andati in un'isola come era una un'hospederia una cosa così $(+)$ perché dovevamo rimanere lì (+) un tem / un periodo (+) eh? E si chiamava Isola dei Fiori a Rio (+) e e IO mi son spaventata tantissimo perché:: era tutto diverso (+) la cosa che mi ha chiamato molta ma molta attenzione $(+)$ era la roba stesa per terra dico "come mai mettono a asciugare la roba per terra" $(+)$ ma non era quello la roba era per prendere il sole per diventare bianca e ma era un costume diverso no? Dopo c'erano delle cose un po' buffe anche che non si può neanche ((risate)) è meglio non dirle / comunque mio cugino era un po' più grande no? (+) e lui 'nsomma c'erano delle ragazze lì lui voleva $(+)$ scherzava così no?

(interrupção da transcrição) 


\section{Análise}

Em uma primeira análise desta entrevista, percebe-se que a língua italiana foi bem conservada. Essa impressão fica evidente levando-se em consideração que a entrevistada vive no Brasil há mais de cinquenta anos e que fala português cotidianamente.

Desde que chegou a Curitiba, teve muito pouco contato com a Itália e com a língua italiana e a partir daí, para facilitar o relacionamento com as crianças da mesma idade (11 anos), resolveu adotar a língua portuguesa de forma definitiva. Fato que se prolongou até a juventude, quando conheceu e se relacionou com um jovem também italiano, que viria a ser seu marido. O casal manteve o hábito de usar até os dias atuais o português como Língua1 (L1). Como prova dessa afirmação, verificou-se que aos filhos não foi ensinada a língua italiana. Apesar de ter utilizado a língua portuguesa por toda uma vida, a manutenção do italiano em um nível que beira a perfeição e a ausência quer de cursos, quer de contato com a língua materna, indica que é um caso evidente de amor à Pátria.

Mesmo assim, fazendo-se uma leitura mais técnica, percebem-se alguns pontos que merecem análise e que denotam a influência do português no italiano.

A primeira palavra que evidencia tal influência no italiano falado é "debitora", na frase: "Mio papà diceva che l'Italia era sua debitora". Este termo deixa clara a fusão entre as duas línguas, pois mantém a raiz da palavra italiana "debito", acrescentando a terminação declinada em português: "devedor - devedora". Do contrário, no italiano, seguindo a regra das palavras masculinas terminadas em "ore", a transformação para o gênero feminino é feita utilizando-se a terminação em "trice", ou seja: "debitore - debitrice". Provavelmente o uso inadequado da palavra "debitora" deve-se ou ao não conhecimento de algumas regras gramaticais do italiano, justificado pelo pouco tempo de estudo quando a entrevistada ainda vivia na Itália, ou à influência direta do português.

Outra palavra que merece uma reflexão é "hospederia". Ela ocorre na frase: "Siamo andati in um'isola che era come un'hospederia". É interessante observar que essa palavra não existe no dicionário italiano. A tradução mais adequada, nesse caso, seria "centri di accoglienza"; um termo relativamente novo, pois se tornou conhecido dos italianos a partir do momento em que a Itália se tornou um país procurado por imigrantes estrangeiros e viu-se na obrigação de criar um espaço para 
recebê-los. Neste contexto, a entrevistada, para se fazer entender, foi "obrigada" a usar um termo genuinamente português, pois há cinquenta anos a expressão "centri di accoglienza" não existia. É possível que a troca da terminação "ária” (normal no português) por "eria" (própria do italiano) tenha ocorrido na tentativa de maquiar a palavra com traços do italiano.

Na sequência da entrevista, a expressão "Mi ha chiamato molta ma molta attenzione" sofre claramente interferência do português. A entrevistada emprega a expressão portuguesa "Me chamou a atenção", traduzindo-a literalmente, em vez de usar "Mi ha colpito molto", frase que certamente seria utilizada por uma falante da língua italiana.

Apesar de a entrevistada demonstrar grande conhecimento da língua materna, os cinquenta anos de contato com outro idioma justificam a presença de algumas alterações lingüísticas peculiares que serão, portanto, analisadas neste trabalho.

O último termo encontrado no trecho transcrito é "costume" na frase: "La roba era per prendere il sole per diventare bianca e ma era un costume diverso no?". Neste caso específico, nota-se a presença no italiano, assim como no português, do dualismo "costume - abitudine" e "costume - hábito". Entretanto, sabe-se que o termo mais frequente no italiano é "abitudine", ao contrário da palavra "costume", que é atualmente pouco utilizada. Já no português, existe um equilíbrio no uso destes dois termos. Em decorrência desta análise, fica difícil determinar as causas mais prováveis da escolha do termo pela entrevistada.

Apesar de os elementos acima analisados revelarem grande influência do português na língua italiana falada, conclui-se que a entrevistada possui um ótimo conhecimento da língua materna. De fato, não só o léxico utilizado é bastante amplo, como tanto o sistema verbal quanto o pronominal foram adequadamente utilizados e o uso das conjunções e dos advérbios foi fiel ao da L1.

Pode-se dizer, portanto, que nesta primeira entrevista a língua italiana foi preservada quase que totalmente, principalmente se for levado em conta o momento da chegada ao Brasil, quando a entrevistada tinha apenas 11 anos e não havia, portanto, na Itália, atingido a maturidade no aprendizado da língua materna. Apesar de uma vida inteira vivida em solo brasileiro, o contato direto com a língua portuguesa e com os falantes desse idioma não ameaçou a sobrevivência da língua italiana. 
TABELA 4.2

Palavras ou trechos identificados e sua correspondência em italiano.

\begin{tabular}{|c|c|c|}
\hline \multicolumn{3}{|c|}{ ENTREVISTA 1} \\
\hline & Italiano incorreto & Italiano correto \\
\hline \multirow{3}{*}{ Palavras } & debitora & debitrice \\
\hline & hospederia & centro d'accoglienza \\
\hline & costume & abitudine \\
\hline Trecho & $\begin{array}{l}\text { Mi ha chiamato } \\
\text { molta attenzione }\end{array}$ & Mi ha molto colpito \\
\hline
\end{tabular}




\section{ENTREVISTA N²}

Sexo:

masculino

Ano de nascimento:

1939

Lugar de nascimento: Palazzolo sull'Oglio, província de Brescia

Partida da Itália:

1966, aos 27 anos

Profissão:

professor de italiano

Doc perché è partito dall'Italia ed è venuto qui?

Inf io (+) ero:: sacerdote $(+)$ eh: ma un sacerdote religioso i miei superiori $(+) \mathrm{mi}$ hanno detto che io avevo le capacità le qualità di essere direttore di un seminario minore qui in Brasile ed allora io sono venuto qui per fare il direttore del seminario e mi hanno spedito a Min / a sud di Minas Gerais (+) e sono stato là un anno

Doc e:: cosa si ricorda dell'Italia nel periodo precedente alla sua partenza come si ricorda l'Italia come si ricorda la gente?

Inf Bom l'talia in quell'epoca negli anni sessanta (+) era un popolo che stava bene $(+)$ io mi ricordo: il passaggio piano piano dal dopoguerra le persone ormai avevano già la loro macchina i miei parenti anche un lavoro abbastanza fisso stabile la mia cittadina $(($ nome $))$ era una città $(+)$ dina molto industriale $(+)$ c'erano molti scioperi $(+)$ per:: migliorare gli stipendi scioperi: per gli stipendi scioperi politici: e varie battaglie fra: democrazia e comunismo (++) ma:: che tutti stavano bene non c'erano poveri per le vie nessuno non c'era gente che chiedeva l'elemosina non c'erano: $(+) /$ mi ricordo $(+)$ che al mio paese è venuto un africano un sacerdote nero è stato l'unico nero che io ho conosciuto nella mia vita che ho incontrato non c'erano (+) / erano (+) lombardi bresciani: e il popolo viveva e lavorava lì nella mia cittadina non c'erano emigrazioni interne (+) e stavano tutti bene mi ricordo (+) di questo

Doc e: quando lei ha saputo o ha scelto uhm: che sarebbe venuto qui in Brasile che idea aveva del Brasile come si immaginava questo paese? 
Inf siccome alcuni padri della mia congregazione (+) (rito) / quando tornavano in Italia facevano delle visite (+) in seminario per parlarci del Brasile (+) per cui si aveva una certa idea ma un'idea più sbagliata di molti neri di molti serpenti di:: una miseria e:: (+) sai avevo: alcune idee giuste ma molte sbagliate (+) non (++) non specchiavano la realtà

Doc e cosa si ricorda del viaggio lei è partito da dove e con chi?

Inf io sono ((risate)) io sono partito con la nave Andrea C. (+) mi ricordo molto di quel viaggio (+) prima di tutto il momento della partenza (+) è il momento (+) per me che era la prima volta ero giovane aveva ventisei ventisette / avevo ventisei ventisette anni (+) sa io e il mio amico ridevamo ma molti piangevano QUANDO la sirena della nave ha dato segno che si staccava (+) (li io) / stava uscendo dal porto ma era / perché suonavano delle musiche di ADDIO ((risate)) per cui era terribile è stato terribile (incomprensibile) non ho pianto sai ma i parenti erano lì vicino a te dopo piano piano la neve si / la nave si allontanava (+) e dopo però quando siamo entrati: (+) nel mare ALLORA è stato un viaggio bellissimo indimenticabile tredici giorni sa $(+)$ ((risate)) al mattina noi andavamo a al mattino alla mattina noi andavamo a: celebrare: la messa ma dopo tutto il giorno era gioco sport leggere film (+) alla sera (+) c'era una: / un complesso musicale che suonava e noi andavamo là: a vedere a ballare ascoltare eccetera musiche italiane prendere delle birre olandesi tedesche eccetera che sulla nave (ce n'erano) di tutti i tipi ho passato tredici giorni molto belli c'é stato un campionato di ping pong e io (+) ho fatto la finale con un'argentina (incomprensibile) (non me la dimenticherò) un'argentina di origine tedesca bionda bella e ho vinto ma: perché mi piaceva molto giocare a: ping pong e:: insomma e sono stati tredici giorni bellissimi

Doc quindi la sua è stata una scelta? Ha deciso di venire qui in Brasile o è stato un po' costretto?

Inf no: il superiore mi ha chiesto un su / il superiore e siccome lui era stato mio professore mio re / direttore eccetera ci: intendavamo e lui mi ha detto "io ho bisogno che tu vada in (Brasile)" ho detto "ci vado"(+) sai non: non avevo ancora preso un 
lavoro fisso là in Italia il posto fisso mi avevano mandato a sostituire un altro padre anziano che era morto allora quando mi ha chiesto non ci ho pensato UN minuto ma non per fatto di obbedienza (ho detto) "ma va bene (+) andiamo (+) in Brasile.

(interrupção da transcrição) 


\section{Análise}

Como já constatado na entrevista anterior, também neste caso é evidente a conservação da língua materna; e, aqui especificamente, pode-se notar ainda certa superioridade de desempenho, ocasionada por fatores que serão analisados a seguir.

Primeiramente, o entrevistado era mais velho que a entrevistada 1. Quando ele chegou ao Brasil, já tinha 27 anos enquanto ela estava com 11 anos. Além disso, ele possuía um nível de escolaridade bem superior, ainda mais se levarmos em consideração que era padre, e, portanto, tinha toda uma formação adquirida dentro de um seminário.

Todavia, fazendo-se uma análise mais detalhada do trecho transcrito, pode-se notar a influência da língua portuguesa em razão dos mais de trinta anos vividos no Brasil e em contato direto com esse idioma. É interessante notar também que quando aqui chegou, ele exercia as funções de padre e que, após algum tempo, afastou-se de suas atividades para casar-se com uma brasileira. Tais acontecimentos fizeram com que o seu contato direto com a língua portuguesa aumentasse consideravelmente. Além disso, o entrevistado declarou ser professor de língua italiana e trabalhar em uma escola particular há mais de dez anos. Todos esses elementos reiteram a ideia da força da influência exercida por uma Língua 2 (L2) no desempenho da L1. O uso, por exemplo, da expressão "bom" para iniciar uma sentença é, por si só, uma prova da influência da L2.

Por diversas vezes aparece, no trecho transcrito, a palavra "padre" referindose a sacerdote, quando no italiano a palavra certa seria "prete". Na língua italiana também existe "padre" neste sentido, porém, com uso muito específico: diante do nome do sacerdote, referindo-se ao sumo pontífice etc. Ou seja, é possível que o uso deste vocábulo por parte do entrevistado tenha ocorrido somente pela influência direta do português.

Outro elemento a ser observado nesta entrevista é o uso do verbo "avere", na frase: "Ero giovane aveva ventisei ventisette anni". Ele é aqui conjugado no imperfeito do indicativo, mas com a terminação errada, pois no italiano a forma correta seria "avevo". Já que no português a terminação do verbo no imperfeito do indicativo em primeira pessoa do singular tem a terminação em "a", pode ter havido 
uma influência direta da L2 na L1. Na transcrição, porém, fica evidente que este foi apenas um lapso por parte do entrevistado, pois logo a seguir efetuou a devida correção: "avevo ventisei ventisette anni". Situações semelhantes a essa reforçam a ideia da força do subconsciente influindo diretamente no desempenho da língua italiana falada.

Fazendo uma análise global desta entrevista, percebe-se, até mais que no caso anterior, a preservação quase perfeita da língua materna o que é confirmado pelo número pequeno de ocorrências analisadas; ocorrências essas que de forma alguma ameaçam o julgamento positivo no desempenho da língua italiana.

\section{TABELA 4.3.}

Palavras ou trechos identificados e sua correspondência em italiano.

\begin{tabular}{|c|c||c|c|}
\hline \multicolumn{5}{|c|}{ ENTREVISTA 2 } \\
\hline Português & Italiano & Italiano incorreto & Italiano correto \\
\hline \hline bom & bene, allora & & \\
\hline padre & prete & & \\
\hline & & io aveva & io avevo \\
\hline
\end{tabular}




\section{ENTREVISTA N³}

Sexo:

masculino

Ano de nascimento:

1940

Lugar de nascimento: Bengasi, Libia

Cidade na Itália:

Lonigo, província de Vicenza

Partida da Itália: 1952, aos 12 anos

Profissão:

aposentado

Doc lei è arrivato qua in Brasile quando? Quanti anni aveva quando siete partiti dall'Italia per il Brasile?

Inf ah il Brasile avevo dodici anni

Doc dodici anni (+) e: quindi lei già studiava in Italia

Inf già

Doc andava a scuola

Inf il primario neh

Doc sì

Inf primo o secondo anno

Doc sì, quindi aveva già cominciato a studiare?

Inf si:: sì

Doc e siete arrivati qui in Brasile in che anno? 
Inf nel cinquantadue

Doc cinquantadue (+) si ricorda il giorno della partenza dall'Italia?

Inf partenza dall'Italia e: $(++++)$ mi sembra che è stato: il giorno (+) cinque o sei di nove / di ottobre $(+)$ e siamo arrivati $(++)$ il giorno dodici $(+)$ novembre

Doc novembre? Più di un mese

Inf eh:

Doc eh e quando ha saputo che: e; tutta la famiglia si sarebbe trasferita in Brasile?

Inf ah prima è venuto mio zio (+) mio zio ((nome )) neh è venuto qui per / nel quarantotto quarantanove (+) e allora ci ha / (+) mia madre il principale scopio

(+) é che:: dice (senti) io con quattro figli da sola $(+)$ prima che $(+)$ viene un'altra guerra $(+++)$ vado a perdere questi quattro figli io vado via eh $(+)$ allora mio zio ha fatto la: la domanda (++) ha fatto i documenti tutti legali neh e siamo venuti in Brasile

Doc quindi quello è stato il motivo principale

Inf ah:: sì

Doc perché la mamma era preoccupata

Inf preoccupata

Doc per la guerra

Inf e i miei zii (+) uno che stava sta qui ha abitato qui (+) nel tempo di guerra è andato in $(+)$ in India (++) lottare contra gli inglesi e l'altro mio zio (nome) è andato in:: e: (++) e:: a Siberia

Doc in Siberia 
Inf eh

Doc e che ricordi ha dell'Italia? (+) all'epoca lei aveva già dodici anni quindi era già: grandicello

Inf eh io io mia mamma mi ha messo in una colonia agricola $(+)$ che formavamo tecnici agricoli non era: a nivello universitario (+) ma sapeva (+) si imparava tutto per l'/ per l'agricultura neh (+) come si piantava il grano come si piantava que / fare l'incerto come è che si dice là in Italia incerto?

Doc l'innesto

Inf eh (++) então a me mi piaceva eh

Doc era una cosa che le piaceva

Inf era ben di (+) diversificata perché era una cosa nel campo dopo c'era da portar le pecore la vicino (+) a pastolare là

Doc a pascolare

Inf eh

Doc e com'era la gente all'epoca (+) in Italia?

Inf ah io: io ho avuto solo conosci / conoscimento coi bambini con i miei i miei colleghi neh

Doc sì

Inf va va tutto bene

Doc in che città italiana vivevate quando siete venuti via dall'Africa? 
Inf a Lonigo

Doc Lonigo

Inf provincia?

Doc di Vicenza

Inf Lonigo è è città $(+)$ dove è nata mia madre

Doc tua mamma

Inf mia mamma era ((cognome))

Doc ah (+) ok e quindi siete partiti per il Brasile con la nave? Si ricorda il nome della nave?

Inf si:: eh Sebastiano Tarotto ((risate))

Doc Cavotto?

Inf eh:

Doc com'era il viaggio in nave?

Inf ah:

Doc cosa si ricorda di questo mese?

Inf uno spettacolo

Doc uno spettacolo ((risate))

Inf a me mi è piaciuto eh 
Doc era bello

Inf perché tutte le notti c'era un cinema un film diferente si stava / sono successe

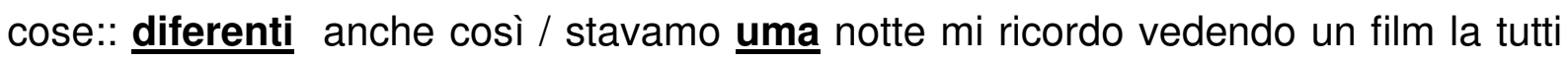
(quasi parlando così) che gli italiani i più vecchi sai (+) quando arrivavano i nostri neh $(++)(($ risate) ) arrivano i nostri dicevano neh $(++)$ un giorno stavamo la tutti vedendo 'sto film_(+) un gabbiano ha battuto nel filo della nave è caduto (+) sulla folla che stava la embaixo

Doc ((risate))

Inf madonna ha fatto un casino ((risate)) (me lo ricordo)

Doc tutti si sono spaventati

Inf eh tutti sì (+) e dopo un altro giorno questa nave 'sto Sebastiano Cabotto era l'ultima viaggio che faceva di ritorno dal Brasile perché era stata venduta per un'altra compagnia $(+)$ era di una compagnia $(+)$ giovanese mi mi sembra che l'altra compagnia era triestina

Doc ah

Inf allora: era di notte così stavano tutti dormindo (+) han han cominciato a a a solt / lanciare i foguetti com'é che dicono?

Doc lanciare i missili (+) dei razzi?

Inf eh madonna (+++) molta gente ha pensato che stavano avvisando perché stava affondando la nave

Doc sì

Inf Madonna:

Doc era un falso allarme invece ((risate)) 
Inf falso allarme

Doc e sulla nave c'era / c'erano persone che venivano da quale parte d'Italia si ricorda?

Inf ah sì (+) mi ricordo (+) del Veneto Piemonte e dopo un un (++) è salita:: quando si è fermata a Napoli anche c'era ( ) ge / gente a Napoli

Doc è partita da Genova la nave vero?

Inf da Ge / eh

Doc da Genova

Inf Genova e Napoli

Doc sì

Inf Napoli las Palmas già in Africa lì neh

Doc sì

Inf las Palmas qui a (+) dove abitava (+) ((nome)) lì a (++) Recife

Doc sì

Inf Recife Rio de Janeiro Rio de Janeiro Santos

Doc e voi vi siete fermati a Santos?

Inf Santos siamo scesi a Santos 


\section{Análise}

Ao contrário das entrevistas precedentes, a entrevista 3 revela uma influência muito maior da língua portuguesa. Isto fica claro pelo grande número de termos e expressões pertencentes à L2 e adaptadas para a L1. Uma das justificativas possíveis é o fato de o entrevistado ter chegado ao Brasil em 1952, quando tinha apenas 12 anos de idade. Nota-se também que ele possuía apenas formação primária e que, ao longo dos mais de cinquenta anos vividos em Curitiba, teve pouco contato com a língua italiana e com membros da comunidade que aqui viviam.

Outro fator que chama a atenção é que o entrevistado declarou nunca ter tido oportunidade de frequentar cursos que possibilitassem melhor manter a língua materna. Portanto, enquanto a L2 evoluía ao longo dos anos, por meio de contato diário com falantes nativos, a L1 perdia, no mesmo ritmo, a sua força.

A seguir serão analisados os casos que merecem especial atenção. Em virtude da presença de muitas ocorrências, como já observado anteriormente, preferiu-se dividi-las em categorias que serão apresentadas a seguir:

\section{- Empréstimos da língua portuguesa}

Primário - palavra que no português identifica uma formação escolar elementar; no italiano, a palavra correta a ser utilizada seria "scuole elementari".

Contra - advérbio da língua portuguesa, que corresponde ao italiano "contro".

Agricultura - substantivo da língua portuguesa, em italiano: "agricoltura".

Então - advérbio que corresponde ao italiano "allora".

Embaixo - advérbio de lugar, equivalente em italiano a "sotto".

Uma - artigo indefinido, que em italiano seria "una". 
Dormindo - gerúndio do verbo "dormir" na língua portuguesa. A forma correta na língua italiana seria "dormendo".

Diferente - adjetivo que no português não apresenta como sinônimo a palavra "diverso", como ocorre na língua italiana. Todavia o mais utilizado em italiano é "diverso", tendo a palavra "differente" um uso muito limitado. Nota-se também que o entrevistado usa a regra do italiano para a formação do plural da mesma palavra: "diferenti".

Os casos acima analisados mostram a influência da L2 no desempenho da L1, certamente motivada pelos poucos anos vividos na Itália - 12 anos precisamente -, em contraste com os mais de cinquenta anos vividos no Brasil.

\section{- Fusão entre as duas línguas}

Nivello - substantivo que apresenta a raiz da palavra portuguesa "nível" e a terminação da mesma palavra que no italiano seria "livello".

Conoscimento - neste caso, temos a raiz da palavra "conoscenza" da língua italiana e a terminação da palavra "conhecimento" da língua portuguesa.

Foguetti - o entrevistado faz uso corretamente da regra italiana para a formação das palavras masculinas no plural, no entanto o faz em uma palavra genuinamente portuguesa, que é "foguetes".

Estes casos podem significar uma tentativa por parte do entrevistado de demonstrar competência na L1, mesmo quando não possuía conhecimento suficiente para este desempenho.

Outro caso que chamou a atenção, e que pode ter relação com os anteriores, foi o uso da palavra "incerto" na frase: "come si piantava il grano....., come si faceva l'incerto...". Vê-se aí possivelmente a tentativa de reproduzir foneticamente de 
modo semelhante ao italiano a palavra portuguesa "enxerto", porém foi criada uma palavra nova, pois em italiano deveria ser utilizado "innesto".

- Uso indevido das preposições

Na frase: "Mio zio è andato a Siberia", nota-se o uso indevido da preposição "a" quando deveria ser utilizada a preposição "in".

Na frase "Mi ricordo venivano del Veneto". O uso de "del" no lugar de "dal" seria o correto na língua italiana.

Foi analisado o uso das preposições sabendo-se que seria impossível para o entrevistado um desempenho melhor, já que ele teve pouco contato com o ensino das regras gramaticais da língua italiana.

Outros casos

A expressão "ultima viaggio" na frase "questa nave 'sto Sebastiano Cabotto era l'ultima viaggio che faceva..." demonstra a total influência da $L 2$ na $L 1$, já que a palavra "viagem" em português é feminina singular, ao contrário do italiano. $\mathrm{O}$ entrevistado concorda o adjetivo ao dizer "ultima viaggio" no lugar de "ultimo viaggio".

As palavras "scopio", "pastolare" e "giovanese" também merecem análise. Trata-se possivelmente de termos que o entrevistado deve ter ouvido em alguma circunstância, porém sem tê-las interiorizado. Isso justificaria a reprodução delas de forma equivocada. As palavras em questão, em italiano, seriam: "scopo", "pascolare" e "genovese".

Em alguns trechos transcritos, verificou-se que a concordância verbal não segue as regras gramaticais italianas, como, por exemplo: 
- "formavamo" na frase: "mia mamma mi ha messo in uma colonia agricola che formavamo tecnici agricoli".

- "vado a perdere" na frase: "prima che viene un'altra guerra vado a perdere questi quattro figli io vado via".

Quanto à palavra "neh", há vários casos em que o entrevistado conclui a frase de forma a pedir uma confirmação ao entrevistador, usando esta expressão que remete ao português "não é verdade?", e que corresponde ao italiano "vero?".

Para finalizar a análise desta entrevista, é importante frisar que a língua italiana manteve-se bem, porém apresenta grande interferência da língua de adoção. Comparativamente às duas primeiras entrevistas, nesta é bem mais visível a presença dos dois códigos linguísticos no discurso. Isso, todavia, é justificável, como já foi dito anteriormente, pelos mais de cinquenta anos de contato com a L2 e sem a convivência direta com a L1.

\section{TABELA 4.4}

Palavras ou trechos identificados e sua correspondência em italiano.

\begin{tabular}{|c||c|c||}
\hline \multicolumn{3}{||c||}{ ENTREVISTA 3 } \\
\hline \hline \multirow{1}{|c|}{$\begin{array}{c}\text { Palavras / trechos } \\
\text { incorreto }\end{array}$} & $\begin{array}{l}\text { Scopio, giovanese, prima } \\
\text { che vado a perdere, } \\
\text { formavamo, pastolare, } \\
\text { ultima viaggio, del } \\
\text { Veneto, diferente, } \\
\text { diferenti, a Siberia }\end{array}$ & $\begin{array}{l}\text { Italiano correto } \\
\text { Scopo, genovese, prima di } \\
\text { perdere, formava, } \\
\text { pascolare, ultimo viaggio, } \\
\text { dal Veneto, diverso, } \\
\text { diversi, in Siberia }\end{array}$ \\
\hline \hline $\begin{array}{c}\text { Português } \\
\text { correto }\end{array}$ & $\begin{array}{l}\text { Primario, agricultura, } \\
\text { dormindo, contra, então, } \\
\text { lá embaixo, uma, neh? }\end{array}$ & $\begin{array}{l}\text { Elementari, agricoltura, } \\
\text { dormendo, contro, allora, li } \\
\text { sotto, una, vero? }\end{array}$ \\
\hline \hline \multirow{2}{\text{Mista}}{} & $\begin{array}{l}\text { Incerto, conoscimento, } \\
\text { foguetti, nivelo }\end{array}$ & $\begin{array}{l}\text { Innesto, conoscenza, } \\
\text { razzi, livello }\end{array}$ \\
\hline \hline
\end{tabular}




\section{ENTREVISTA $N^{\circ} 4$}

Sexo:

masculino

Ano de nascimento:

1929

Lugar de nascimento: Venezia

Partida da Itália:

1951, aos 22 anos

Profissão:

aposentado

Doc: Parlando della partenza dall'Italia e Lei è venuto qui in nave naturalmente

Inf: in nave giusto

Doc: cosa si ricorda del viaggio in nave?

Inf: tutto perfettamente mi ricordo tutto

Doc: Ci racconti qualcosa (+) degli episodi

Inf: (incomprensibile) degli episodi tutto qua prima cosa so/ son mbarcato a Genova $(++)$ giusto su una nave mista (+) passeggeri e carico neh i passeggeri non c'era non era cabine $(+)$ era un $(++)$ (incomprensibile) come come come i buoi come se ((risate)) era una cosa interessante neh era alojamento per uomini e alojamento per donne e bambini (+) e cuccette era cinque cinque piani neh então quelle persone si alzavano lì/ abbiamo navigato durante sedici giorni (++) per arrivare qui (+) a Rio de Janeiro neh (++) e::: durante la nave: (+) il comandante a: cercava di mantenere insomma:: le persone un po' motivate perché è logico non si sapeva cosa si trovava né (+) ma (+) abbiamo trascorso questi sedici giorni (+) e (incomprensibile) posso dirti anche con una certa alleGRIA (++) perché la gente non sapeva cosa trovava domani neh $(++)$ eh logicamente è stata una sorpre/ arrivando a Rio de Janeiro $(+++)$ è stata una cosa interessante neh $(++)$ tre quattro ragazzi $(++)$ abbiamo preso un un um onibus come si dice un tram e siamo fatto un giro neh 
(incomprensibile) tante volontà (incomprensibile) non avevamo voglia di ritornare neh e dopo cosa è successo? (+) continuava ancora abbiamo chiesto perché non si parlava male male neh $(+)$ (incomprensibile) inton siamo scesi e abbiamo fatto un po' (+) un po' di soldi ciascuno per prendere un taxi e per ritornare al porto questa è stata la cosa più mi ha $(++)$ e dopo il giorno dopo siamo arrivati a Santos siamo scesi a Santos inton siamo stati accolti dalla dalla:: con (++) (incomprensibile) dall:: immigrazione neh l'immigrazione che ha fatto i documenti para $(+)$ per potere inton rimanere qui in Brasile neh (+) il giorno dopo son arrivato a Curitiba (+) sono arrivato a Curitiba il giorno due novembre (++) e a Santos sono cittadino italiano in Brasile il trentuno ottobre del millenovecentocinquantuno

Doc: La prima impressione di Rio de Janeiro perché è stata la prima $(+)$ città brasiliana che ha visto?

Inf: Ah:: adesso è difficile di dire questo perché la gente stava con la testa così confusa eh tutta una cosa nuova una cosa diferente nel senso non non ne imaginavo cosa fosse Rio de Janeiro non sapevo che c'era il Cristo Redentor (+) non sapevo che c'era il Corcovado sapevo che c'era la gente di colore questo si sapeva ma (++) sulle altre cose no neh

Doc: è stata una bell'immagine?

Inf: Sì un'immagine diferente veramente bella perché logico Venezia è una cosa e Rio de Janeiro è un'altra cosa (+) ecco ma posso dirti (+) una persona che nasce a Venezia ha una certa nozione di turismo (++) perché abita a Venezia il movimento di Venezia e tutto questo $(+)$ e Rio per me era una cosa differente neh:: posso dire una cosa BELLA però senza nozione nessuna neh

Doc: E Curitiba invece?

Inf: oh Curitiba l'ho trovata piccolina $(++)$ una città veramente provinciana $(+)$ comparando con le città d'Italia che conoscevo neh giusto e Curitiba è una città bellina ma piccolina (++) eh:: pos/ un grande paese da noi altri (+) e:: si conosce tutti neh parlando del Veneto eh cosa succede? Qua a Curitiba oh:: (incomprensibile) una cosa che era una famiglia praticamente inton sono molte le persone che si 
conosce/ perché la città era pic/ non aveva preso ancora eh:: una città grande come si vede oggi $(+)$ Curitiba è cresciuta molto neh in quel tempo $(+)$ Curitiba aveva un centottanta duecento mila abitanti $(+)$ quando sono arrivato io nel cinquantuno $(+)$ oggi è una città bem diferente neh

(Interrupção da transcrição) 


\section{Análise}

Também nesta entrevista, é marcante a boa preservação da língua italiana. 0 entrevistado em questão veio para o Brasil com 22 anos de idade, ou seja, já tinha certa formação na língua italiana. Além disso, ao longo de todos esses anos no Brasil, tem participado periodicamente de atividades junto à comunidade italiana de Curitiba.

Porém o contato de todos esses anos, tanto com a sociedade curitibana de um modo geral, quanto com a sua própria família, formada a partir da união com uma brasileira, contribuíram para que, mesmo de forma sutil, houvesse influência da L2 no desempenho da L1.

A seguir serão analisadas as principais ocorrências encontradas no trecho transcrito:

Em primeiro lugar, identificamos dois casos de autocorreção: o entrevistado usa a palavra inicialmente em português, para, logo em seguida, corrigi-la pronunciando-a no italiano correto.

Ocorrência 1: "abbiamo preso um um um ônibus come si dice un tram".

Ocorrência 2: "l'immigrazione ha fatto i documenti para per poter rimanere qui in Brasile".

Vê-se perfeitamente que no discurso surge de forma mais espontânea a palavra em português, enquanto que a palavra em italiano vem só após um momento de reflexão.

Como já ocorreu durante a análise da entrevista 3, o adjetivo "diferente", mais comum em português, é usado no lugar de "diverso", que é o mais difundido na língua italiana.

Outro aspecto interessante de se observar no trecho transcrito é a presença dos termos "então" e "inton". O primeiro é um claro empréstimo da língua portuguesa, já que em italiano a palavra a ser usada é "allora". No segundo caso, há um desejo evidente de italianizar foneticamente a mesma palavra. 
Existem também algumas falhas na conjugação dos verbos, como:

- "non c'era cabine", quando deveria ter dito: "non c'erano cabine";

- "noi siamo fatto un giro", no lugar de: "noi abbiamo fatto un giro" ou "ci siamo fatti un giro".

Essas incorreções podem ser atribuídas ao longo período em que o entrevistado ficou longe das regras gramaticais do italiano. Pode-se ainda levar em conta o fator emocional uma vez que estava falando sobre a sua vida, a sua história.

O termo "provinciana", na frase: "Curitiba l'ho trovata piccolina una città veramente provinciana", usado em lugar da palavra italiana "provinciale", é genuinamente uma palavra portuguesa.

Também pertence ao português o vocábulo "alojamento", empregado na frase: "Era uma cosa interessante neh era alojamento per uomini e alojamento per donne e bambini", quando deveria ter sido usada a palavra "alloggio".

O entrevistado 4 usa inúmeras vezes a expressão "neh" para concluir suas frases, provavelmente se trata de um hábito brasileiro absorvido por um italiano ao longo do tempo.

Como reflexão final desta análise, como já frisado várias vezes anteriormente, a competência na língua italiana é muito boa e as ocorrências merecedoras de análise são normais em pessoas que vivem sem contato com a língua materna por um longo período. 
TABELA 4.5

Palavras ou trechos identificados e sua correspondência em italiano.

\begin{tabular}{|c|c|c|c|}
\hline \multicolumn{4}{|c|}{ ENTREVISTA 4} \\
\hline Português & Italiano & Italiano incorreto & Italiano correto \\
\hline neh? & $\begin{array}{c}\text { vero? } \\
\text { no? }\end{array}$ & & \\
\hline ônibus & autobus & & \\
\hline para & per & & \\
\hline \multirow[t]{3}{*}{ diferente } & diverso & & \\
\hline & & non c'era cabine & non c'erano cabine \\
\hline & & $\begin{array}{l}\text { noi siamo fatto un } \\
\text { giro }\end{array}$ & $\begin{array}{c}\text { abbiamo fatto } \\
\text { un giro, } \\
\text { ci siamo fatti un } \\
\text { giro }\end{array}$ \\
\hline então & allora & & \\
\hline provinciana & provinciale & & \\
\hline
\end{tabular}




\section{ENTREVISTA $N^{\circ} 5$}

Sexo: $\quad$ feminino

Ano de nascimento: $\quad 1939$

Lugar de nascimento: Vicenza

Partida da Itália: $\quad$ 1948, aos 9 anos

Profissão: $\quad$ comerciante

Doc: Perché siete venuti in Brasile? Si ricorda la ragione?

Inf: Sì:: $(+)$ e:: mio papà $(+)$ papà aveva finito la guerra + e la non c'era del lavoro $(+++)$ é stato chiamato (per venire) in Brasile $(++)$ per l'arch/ l'architetto ma a Niema/ Niemeyer $(+++)$ e:: $(++++)$ ha lavorato con lui un anno $(++)$ e dopo e:: $(+++++++++++)$ precisava $(+++)$ venire via per $(+++)$ per :: $(++)$ il la temperatura (era) molto alta $(++)$ e non $(++)$ si acostumava

Doc: E quando le hanno detto che voi dovevate lasciare l'Italia $(++)$ e dovevate venire qui in Brasile? Come gliel'hanno detto? Si ricorda?

Inf: No tanto perché:: (++) e:: mio papà è venuto un anno prima $(+++)$ e:: io e mia mia mamma siamo venute dopo un anno (+++) allora non no non sapre/ (+++) non sapr/ (++) non saprei dirti $(++)$ il motivo com'è stato:: non mi ricordo

Doc: $\mathrm{E}$ ma quando Lei ha saputo che dovevate venire qui in Brasile era contenta era felice o era dispiaciuta di lasciare l'Italia?

Inf: Bom mia mamma (++) piangeva solo piangeva ( $\underline{\text { neh }})(++)$ io era piccola então no no $(++)$ non sapeva ::: (++) come $(++++)$ neh $(++)$ então è stato assim $(++)$ un:: viaggio molto brutto

Doc: Cosa si ricorda del viaggio? 
Inf: Niente $(++)$ e:: $(+++)$ no noi stavamo num:: numa cabine $(+++)$ (incomprensibile) sotto neh $(++++)$ e:: mia mamma praticamente stava in letto il tempo $(++)$ inteiro

Doc: Perché?

Inf: Perché:: $(++++)$ si sentiva male

Doc: si sentiva male

Inf: si sentiva male

Doc: e Lei invece cosa faceva?

Inf: Bom $(++)$ io andavo per ci/ per $(+++)$ e:: per $(++)$ cima per $(++)$ baixo

(Interrupção da gravação)

Doc: Allora stava dicendo della nave cosa faceva Lei?

Inf: Giocava $(($ risate)) giocava $(+++)$ sola non c'era molto $(++)$ molte cose da fare

Doc: E quando siete arrivati in Brasile si ricorda che mese era?

Inf: No

Doc: No

Inf: No

Doc: E quando ha visto/ dove siete sbarcati?

Inf: A Rio de Janeiro 
Doc: E la prima immagine che si ricorda di Rio de Janeiro come è che Le è sembrata questa città nuova? (++) Ha dei ricordi?

Inf: Un poco $(++)$ molto poco $(+++)$ e:: $(++)$ quando noi siamo arrivati $(++++)$ non siamo stati a Rio (+) siamo venuti qua per Curitiba $(++)$ e da Curitiba Campo Largo $(+++)$ perché mio papà $(+)$ lavorava in una numa : $(++)$ fabbrica di ceramiche $(++)$ e:: $(++++++)$ (incomprensibile) ele era pintor

Doc: Sì

Inf: E lavorava in:: ceramiche $(++)$ pintava a mano

Doc: Sì

Inf: Siamo stati sei anni in Campo Largo $(++)$ dopo siamo (+) ritornati qua a Curitiba

Doc: E voi a casa parlavate solo l'italiano vero quando siete appena arrivati

Inf: Sì sì sì

Doc: E poi

[

Inf: solo l'italiano

Doc: il portoghese come è che l'ha imparato?

Inf: a scuola

(Interrupção da transcrição) 


\section{Análise}

Em uma primeira análise, é preciso salientar que a entrevistada número 5 foi aquela que obteve o menor índice de desempenho na língua italiana falada. Como se verá a seguir, o número de termos passíveis de análise é muito grande e, além disso, é marcado pelo uso da língua portuguesa como uma espécie de apoio. A justificativa mais plausível para este fenômeno pode ser atribuída ao fato de a referida entrevistada ter vindo ao Brasil quando contava com apenas nove anos de idade, ou seja, pouco ou quase nada obteve na Itália em termos de formação educacional.

Outro fator que pode explicar este fraco desempenho é que, logo que chegou ao Brasil, começou a estudar. $E$ todo o estudo foi desenvolvido em língua portuguesa, o que, portanto, afastou-a mais e mais da L1.

Além disso, conforme a própria entrevistada, a sua família ficou instalada em uma região distante dos principais núcleos italianos, tornando ainda mais difícil o contato com a língua italiana.

Em seguida, será analisado o trecho transcrito acima; porém, em virtude do grande número de ocorrências, como já feito anteriormente, elas serão divididas também em categorias.

Empréstimos do português - verbos

- "precisava" na frase: "mio papà........ precisava venire via", quando o correto, na língua italiana, deveria ser "doveva".

- "acostumava" na frase: "la temperatura era molto alta e lui non si acostumava", neste caso o verbo mais adequado em italiano seria "si abituava".

- "era" na frase: "io era piccola", quando a conjugação correta em italiano seria "io ero".

- "pintava" na frase "lui lavorava in ceramiche pintava a mano", neste caso o verbo correto seria "dipingeva". 
Nas ocorrências acima, nota-se a direta influência da $L 2$ na $L 1$, pois a entrevistada, por falta de recursos, acaba por fazer uma espécie de mescla entre os dois códigos linguísticos.

\section{Empréstimos do português - expressões}

- "bom", "então", "neh". Trata-se de três expressões próprias da língua portuguesa, muito utilizadas pela entrevistada e que reforçam a idéia da falta de habilidade no desempenho da língua materna.

As expressões citadas são, como já foi dito, muito comuns, tanto que aparecem por diversas vezes também nas entrevistas analisadas anteriormente, fato este que demonstra um traço que aproxima de certa forma os imigrantes de um mesmo período, no que se refere ao desempenho da $L 1$ falada.

- "assim" na frase: "è stato assim un viaggio molto brutto". O advérbio correto na língua italiana seria "cosi”.

Empréstimos do português - frases

- "numa cabine', em: "noi stavamo num numa cabine", quando a expressão em italiano deveria ser "in una cabina".

- "tempo inteiro", em: "mia mamma stava in letto il tempo inteiro", quando a expressão italiana poderia ser "tutto il tempo".

- "cima per baixo", em: "io andavo per cima per baixo". A expressão italiana poderia ser: "andavo da una parte all'altra". Nota-se aqui uma tentativa de italianizar a frase usando a preposição "per" no lugar de "para".

- "ele era pintor", a frase em italiano seria: "lui era pittore". 


\section{Fusão entre as duas línguas}

- "sapeva" na frase: "io era piccola então non sapeva...".

- "giocava", na frase: "io giocava sola".

Nestas duas ocorrências, a entrevistada, mesmo usando o verbo italiano adequado, se deixa influenciar pelo português quando efetua a conjugação no Imperfeito do Indicativo.

\section{Preposições}

- "per" na frase: "è stato chiamato per venire in Brasile per l'architetto...". Nesta frase a preposição que deveria ser usada, segundo as normas gramaticais da língua italiana, è "dall", por tratar-se de uma frase passiva.

- "in letto", na frase: "mia mamma praticamente stava in letto il tempo intiero". A preposição a ser utilizada neste caso seria "a".

- "per Curitiba", na frase: "siamo venuti qua per Curitiba", a preposição adequada em italiano seria "a".

- "in ceramiche" na frase: "lavorava in ceramiche", a entrevistada usa aqui "in" no lugar de "con le".

- "in Campo Largo" na frase: "siamo stati sei anni in Campo Largo", a preposição "a" deveria ter sido usada neste caso.

No uso dessas preposições, observa-se que a entrevistada é diretamente influenciada pela $L 2$, que é a mais conhecida e a mais empregada no seu dia-a-dia.

Para concluir a análise desta entrevista, serão abordadas algumas situações em particular que merecem destaque.

As longas pausas durante a entrevista podem ser consideradas fator de insegurança no desempenho da L1. Na ausência de outros recursos, a entrevistada via-se na dependência de "ganhar tempo" para refletir sobre o que deveria falar.

O uso excessivo de palavras e expressões próprias do português demonstra a impossibilidade de um desempenho mais satisfatório. A preferência por respostas 
breves comprova também a dificuldade de se expressar em uma língua que, por diversas vezes durante a entrevista, dava mostras de ser, para ela, quase uma língua desconhecida.

Não obstante todas as dificuldades aqui citadas, é necessário a enaltecer o grande esforço que a entrevistada demonstrou, tanto na vontade de colaborar da melhor forma possível com este trabalho, como na tentativa de buscar dentro de si própria rastros de um idioma não utilizado por ela há muito tempo e que se transformou quase em uma língua desconhecida. Levando-se tudo isso em consideração, pode ser considerado satisfatório o italiano usado pela entrevistada número 5.

\section{TABELA 4.6.}

Palavras ou trechos identificados e sua correspondência em italiano.

\begin{tabular}{|c|c|c|}
\hline \multicolumn{3}{|c|}{ ENTREVISTA 5} \\
\hline & Palavras / trechos & Italiano correto \\
\hline $\begin{array}{l}\text { Italiano } \\
\text { incorreto }\end{array}$ & $\begin{array}{l}\text { Per l'architetto, lei stava } \\
\text { in letto il tempo inteiro, } \\
\text { siamo venuti per } \\
\text { Curitiba, lavorava in } \\
\text { ceramiche, siamo stati } \\
\text { sei anni in Campo } \\
\text { Largo }\end{array}$ & $\begin{array}{l}\text { dall'architetto, lei stava a } \\
\text { letto tutto il tempo, siamo } \\
\text { venuti a Curitiba, } \\
\text { lavorava con le } \\
\text { ceramiche, siamo stati sei } \\
\text { anni a Campo Largo }\end{array}$ \\
\hline $\begin{array}{l}\text { Português } \\
\text { correto }\end{array}$ & $\begin{array}{l}\text { Precisava, acostumava, } \\
\text { bom, neh?, era, então, } \\
\text { assim, numa cabine, ele } \\
\text { era pintor, pintava }\end{array}$ & $\begin{array}{l}\text { doveva, abituava, allora, } \\
\text { vero?, ero, allora, così, in } \\
\text { una cabina, lui era pittore }\end{array}$ \\
\hline Mista & $\begin{array}{l}\text { io sapeva, io giocava, } \\
\text { cima per baixo }\end{array}$ & $\begin{array}{l}\text { io sapevo, io giocavo, da } \\
\text { una parte all'altra }\end{array}$ \\
\hline
\end{tabular}




\section{ENTREVISTA N6}

Sexo:

masculino

Ano de nascimento:

1942

Lugar de nascimento: $\quad$ San Lorenzo, província de Trento

Partida da Itália:

1969, aos 27 anos

Profissão:

professor de italiano

Doc in che anno Lei è partito dall'Italia per venire qui in Brasile?

Inf sono partito nel sessantanove $(+++)$ sì nel sessantanove

Doc quanti anni aveva?

Inf avevo 27 anni

Doc quindi Lei aveva già:: finito gli studi in Italia?

Inf sì

Doc si era laureato?

Inf no laureato non / no perché io ho fatto gli studi: eh:: di filosofia e teologia

(+) ma:: ah:: in seminario e perciò (++) non c'era un titolo di studi (+) equivalente alla laurea

Doc e e negli anni in cui Lei studiava prima di partire per il Brasile com'era l'Italia?

Inf Eh:: era un'Italia molto bella molto vivace molto $(++)$ eh $(++)$ che stava cercando eh:: come dire un rinnovamento $(++)$ forse spirituale proprio eh:: era 
l'epoca delle:: (+ ) dei movimenti studenteschi (+) nel sessantotto (+) ma era l'epoca che: era stata preceduta anche dal Concilio Vaticano Secondo con una / (+) che aveva portato in Italia una (+) secondo me un bellissimo (+) eh:: (+) una bellissima ricerca di conoscenza (+) del del mondo (+) eh: di vedere oltre oltre l'Italia eh? (++) è stato un / era un'epoca molto bella e I'ITALIA anche così come eh: dal punto di vista sociale era in (+) in effervescenza c'erano molti movimenti operai politicamente era $(+)$ era molto $(+)$ interessante eh:: $(++)$ sì $(+)$ ho un ottimo ricordo di quell'epoca

Doc e allora cosa l'ha spinta a lasciare l'Italia e a:: venire qui in Brasile?

Inf dunque come ti ho detto io ho fatto gli studi di teologia sono diventato prete (+) e volevo venire qui in: in Brasile (+) per aiutare la chiesa di qui che sapevo ahn: aveva (+) grande necessità di di preti di sacerdoti perché (+) per esempio a San Paolo (+) che: già a quell'epoca era una città eh: (+) mostruosa di grande (++) ahn: c'erano meno preti che nella diocesi di Trento dove io (+) sono nato e cresciuto eh:: (++++) eh:: la provincia di Trento e la diocesi avevano quattrocento mila abitanti e San Paolo ne aveva otto milioni

Doc quindi siete venuti qui per portare un po' di supporto ahn:: spirituale?

Inf si (++) ahn:: non tanto supporto credo che la la: la:: il nostro desiderio il MIO desiderio era quello di eh:: (++) di dare eh:: alla gente eh? Un po' più di eh:: (++) si supporto assistenza MA di dare una una scintilla che li portasse a: ad andare da soli ad avere più (+) più::

Doc più indipendenza

Inf indipendenza

Doc Lei è partito insieme ad un gruppo o è partito da solo?

Inf no siamo venuti / eravamo (++) sei preti sulla stessa nave (+) eh:: quattro siamo venuti a San Paolo (+) o siamo andati a San Paolo e due eh:: avevano come destino Rio Grande do Sul 
Doc cosa si aspettava dal Brasile? qual'era l'idea che Lei aveva di questo paese prima di intraprendere questo viaggio?

Inf eh:: io ho fatto tutta la teologia in un seminario eh:: (+) di Verona (+) che si chiamava ((nome del seminario)) un seminario molto ahn:: (++) molto all'avanguardia (+) tanto per quanto riguarda gli studi come per quanto riguarda la forma / riguardava la formazione dei preti (+) dei seminaristi eh:: (++) e lì c'era una formazione specifica rispetto de / di dell'America Latina (+) perciò eravamo a conoscenza di moltissime cose che $(+)$ in altre scuole non (+) non si sapevano (++) eh:: avevamo incontri con moltissimi (+) eh::: (+) non solo vescovi o sacerdoti ma intellettuali (+) eh:: latino americani $(++)$ messicani onduregni e: e::: che altro: $(++)$ abbiamo conosciuto moltissimi BRASILIANI argentini eh:: boliviani ne abbiamo conosciuti della gente (+) ogni fine settimana venivano 'na decina di vescovi dal concilio veniva $(+)$ a cercare qualcuno che potesse ((risate)) andare a dargli una mano (++) e allora 'nsomma $(++)$ abbiamo abbiamo sentito molte cose

Doc qual'era l'idea principale $(+)$ che si tramandava del Brasile?

Inf bene: nonostante tutto quello che possono avere (+) insegnato e:: comunicato rispetto della situazione del Brasile (+) io avevo un'idea che era (+) abbastanza credo comune di un paese molto povero e: questo credo che sia vero eh? (almeno) fino ad oggi mio Dio non si può nascondere ma (+) eh::: (+++) ma: (+) l'idea che avevo era un po' (+) esagerata vai $(+)$ credo

Doc siete partiti dall'Italia quando (+) per venire qui in Brasile e da dove?

Inf bene siamo partiti allora già che: tu vuoi sapere / beh ((risate)) sono venuto con la nave partiti da Genova (++) se non mi sbaglio alla fine / no no non mi sbaglio alla fine di ottobre (+) ma non mi ricordo perfettamente se è stato il giorno ventuno ventidue ventitre (+) e siamo arrivati il giorno sei (+) novembre a Rio de Janeiro

Doc che ricordi ha della nave qualche immagine particolare che le è rimasta impressa $(+++)$ la gente? 
Inf no la gente non / se no (+) no non (+) quello che mi che mi ricordo è che con gli altri colleghi eravamo preoccupatissimi di imparare:: il portoghese (+) e dopo (+) pochi giorni forse un giorno due tre forse che eravamo sulla nave abbiamo conosciuto una suora (+) di una cittadina dell'interno di San Paolo e lei ha cominciato a darci lezione di (+) portoghese (+) per sei ore al giorno (++) questo me lo ricordo molto bene ((risate)) dopo mi ricordo che mangiavo patate come (+) MAI nella mia vita e quando il capitano nell'ultimo giorno è passato di tavolo in tavolo a chiedere eh:: se eravamo contenti e questo e quello io gli ho chiesto "ma mi dica quante tonnellate di patate abbiamo imbarcato a Genova?" ((risate)) lui ci è rimasto male poveretto (+) che ci si può fare

Doc c'era gente che veniva un po' da dall'Italia intera su questa nave?

Inf credo di si beh: c'era / la nave era piena (era) l'Augustus il suo ultimo viaggio $(++)$ dopo questo viaggio ti dico é $(++)$ stata venduta al ferro vecchio ((risate)) eh:: e c'era molta gente adesso io non mi ricordo di essermi interessato se / ma italiani non erano molti (++) e c'erano molti (+) brasiliani e argentini che erano stati in Italia per:: (+) delle vacanze per trovare dei parenti: cose di questo tipo italiani pochissimi (+) non mi ricordo ma non: credo che eravamo solo noi $(++)$ e c'era il cardinale di Rio de Janeiro $(+++)$ che si chiamava ((cognome)) ma non era ((nome )) era stato suo ausiliare e in quell'epoca era già vescovo di Recife $(++)$ lui era $(++)$ don ((nome e cognome)) era molto conservatore lui

Doc quando siete arrivati a Rio de Janeiro qual'è stata la prima immagine che ha avuto di questa città? Come se la ricorda Rio de Janeiro?

Inf eh:: l'unico ricordo che ho fino ad oggi fino adesso è che (++) quando siamo andati sul Corcovado (++) eh: siamo passati nella:: floresta da Tijuca $(+++)$ mi ha sbalordito il (+) la vivacità del: della foresta $(++)$ io: non avevo mai visto un: bosco come ci sono lì dalle mie parti in Trentino (+) così:: pieno di alberi che (+) sarebbe stato impossibile entrarci 


\section{Análise}

O entrevistado em questão veio para o Brasil em 1969, aos 27 anos de idade. Era padre e possuía formação teológica feita em um seminário na Itália. Segundo as suas próprias declarações, foi convidado a trabalhar no Brasil, que necessitava de sacerdotes naquela época.

Após trabalhar em território brasileiro por determinado tempo, abandonou o sacerdócio e casou-se com uma brasileira. Este fato e os quase quarenta anos vividos no Brasil, entretanto, não foram suficientes para que houvesse perda ou qualquer tipo de alteração no seu desempenho da língua materna, que foi conservada integralmente.

Provavelmente dois fatores favoreceram a manutenção da língua com ótimo desempenho: o primeiro, o de jamais ter perdido o contato com os italianos e com a língua italiana, pois retorna à Itália periodicamente; o segundo fator determinante é que desempenha, há mais de dez anos, as funções de professor de língua italiana, em uma escola da qual ele próprio é proprietário.

Todos os comentários feitos acerca desta entrevista podem ser amplamente comprovados na transcrição dela, uma vez que na escolha do léxico, nas concordâncias, na riqueza do texto, observa-se claramente o domínio da L1. No trecho transcrito não foram encontrados elementos que demonstrassem qualquer dificuldade no trato com a língua, nem influência da língua portuguesa, nem falta de recursos quanto à gramática italiana, ou de qualquer outra ordem. Ao contrário, verificou-se ao longo do diálogo a riqueza e grande espontaneidade que são características dos nativos, reforçadas pelo nível de preparo ao longo de uma vida de estudos.

De todas as entrevistas apresentadas neste trabalho, esta é, sem sombra de dúvida, a que melhor testemunha que, mesmo se tendo vivido quase meio século em contato direto com uma L2, pode-se sim preservar de modo íntegro a língua materna. Mas é evidente que caso como este representa uma exceção. 


\section{CONSIDERAÇÕES GERAIS}

Considerando as entrevistas de um modo global, é possível verificar a perda na qualidade do discurso na língua italiana, fenômeno natural em indivíduos que se estão distantes do seu país de origem. Essa conclusão baseia-se na definição de "língua" de Vincenzo Monti quando diz que língua "è un organismo vivente".

Além disso, conforme vários linguistas, a língua italiana sofreu nas últimas décadas um processo evolutivo ainda mais significativo que o considerado normal em qualquer outra língua, com a criação de neologismos, novas formas verbais e lexicais e o empréstimo de palavras estrangeiras.

Ainda que o processo evolutivo da língua italiana tenha sido muito significativo nas últimas décadas, é certo que, para um falante que vive na Itália, a assimilação dessas transformações ocorreu de forma automática, enquanto o mesmo não se pode dizer dos falantes que acompanharam de longe este processo.

Neste último caso enquadram-se os indivíduos objeto deste trabalho, pois algo em torno de cinco décadas de afastamento justificariam até uma perda total da língua falada. Perda essa que não ocorreu absolutamente com os entrevistados, o que não significa dizer que não houve transformação ou perda parcial, quer provocadas pela influência direta da $L 2$ na $L 1$, quer pela falta de interesse pessoal em procurar meios para preservar a língua materna.

Ao tratar de cada entrevista de um modo mais singular ou específico, chama a atenção os seguintes casos:

Uma delas, a de número 6, alcançou níveis de perfeição, algo praticamente impossível para um indivíduo que vive longe da Itália há quarenta anos.

Duas delas - as de número 1 e 2 - também merecem destaque do ponto de vista do desempenho, sobretudo se for considerado o processo de transformação da língua italiana ocorrido nas últimas décadas.

$\mathrm{Na}$ entrevista de número 2, o ótimo desempenho pode perfeitamente ser justificado, seja pelo nível de escolaridade do entrevistado, seja pela idade que ele tinha quando aqui chegou, o que Ihe permitiu ainda na Itália a aquisição de toda uma bagagem linguístico-cultural. Acrescente-se a estes 0 fato de estar ele desenvolvendo aqui, já há algum tempo, o papel de professor de italiano. 
Já na entrevista de número 1, as justificativas para ótima preservação da L1 são bem diversas. Trata-se de uma pessoa que demonstra claramente, na maneira de se expressar, um grande amor tanto pela Pátria quanto pela língua. Mesmo tendo vivido distante de um ambiente propício para a conservação da língua, o seu grande interesse fez com que, com grande esforço, fosse encontrando oportunidades para relacionar-se com o mundo italiano.

A entrevista número 4 indica também um indivíduo com um bom nível quanto ao discurso na L1 que pode ser atribuído ao fato de, segundo as suas próprias palavras, jamais ter abandonado o meio italiano. Isso porque, desde a sua chegada, ele participa de inúmeros eventos organizados por membros da comunidade italiana que, como ele, aqui chegaram na década de cinquenta.

$\mathrm{Na}$ entrevista de número 3, o entrevistado, mesmo não tendo atingido níveis tão altos quanto aqueles tratados anteriormente e mesmo tendo sofrido a evidente influência da L2, conseguiu desenvolver um diálogo bastante satisfatório, a ponto de permitir-lhe ter uma conversação tranqüila com qualquer italiano que dele se aproximasse.

Finalizando as observações, na entrevista de número 5 a entrevistada mostrou claramente ter dificuldades no desenvolvimento do discurso na língua materna. Era visível o desejo de buscar na lembrança palavras ou expressões em italiano, mesmo precisando de muito tempo para uma melhor reflexão. Entre as causas que podem ter contribuído para esse resultado e indo além daquelas justificativas já mencionadas - como a influência da L2 e o contato com brasileiros -, podemos enumerar outras, como, por exemplo, a falta de oportunidades para um contato maior com a comunidade italiana, ou quem sabe até a falta de desejo em preservar um idioma que se tornara quase estranho em virtude do tempo.

Apesar de serem uma pequena amostra de todo um quadro, as entrevistas deste estudo são a prova incontestável de que é possível a manutenção da língua materna mesmo longe do país de origem, pois de um total de seis entrevistas, quatro podem ser consideradas ótimas ou boas, uma satisfatória e somente uma reputada como insatisfatória. Isso é uma visível demonstração de que os imigrantes que chegaram a Curitiba logo após a Segunda Guerra conseguiram preservar a sua língua materna.

Além disso, como Curitiba é uma cidade que oferece muitas possibilidades de acesso ao mundo italiano, seja ele cultural, histórico ou linguístico, quem sabe esteja 
aí o segredo que justifica este resultado positivo em relação à conservação da língua italiana pelos imigrantes da Península. 


\section{CONCLUSÕES}

Primeiramente, é inegável a riqueza de um assunto como o da imigração italiana no Brasil. A necessidade de aprofundar o conhecimento a respeito desse tema, buscando na literatura dos últimos cem anos algo que tratasse do assunto, revela uma carência no que diz respeito à imigração do pós-guerra em Curitiba, pois quase a totalidade das informações referiam-se a primeira grande chegada de italianos nesta cidade.

Além dos livros que, mesmo não sendo muitos, ajudam a compreender de certa forma a trajetória daquele italiano que veio no final do século XIX para o Brasil, havia também a possibilidade de se buscar dentro dos núcleos italianos existentes na capital paranaense, através de relatos de descendentes, informações a respeito.

Porém, para ampliar o estudo em relação a este fenômeno, que é o desenvolvimento pleno dos italianos em território paranaense nos últimos 130 anos, era necessário conhecer mais a fundo a história daquele que partiu da Itália aproximadamente há cinqüenta anos.

A busca iniciou-se, então, dentro dos núcleos. Entretanto, surpreendentemente, nada foi encontrado que pudesse contribuir para o início desta pesquisa. Ou seja, este italiano, que emigrou mais recentemente, não se encontrava neste local; mais ainda, ninguém tinha informações que permitissem a sua localização.

Todas essas dificuldades contribuíam para que esse assunto fosse aprofundado. Para tanto, o trabalho começou através de contatos em locais onde existia o fluxo de imigrantes italianos, como, por exemplo, as associações culturais, as escolas de idiomas, as universidades etc. A partir daí, foi possível empreender o presente trabalho.

Tendo como exemplo todo o estudo já desenvolvido no Estado de São Paulo sobre 0 aspecto linguístico nas comunidades italianas, é que se decidiu analisar a língua dos imigrantes que chegaram em Curitiba por volta de 1950.

Ainda que um número restrito de entrevistas tenha sido analisado, em virtude das dificuldades aqui já mencionadas, a opinião formada após um estudo do 
material disponível é que, embora passados aproximadamente cinqüenta anos, a língua italiana foi muito bem preservada pelo imigrante italiano residente em Curitiba.

A intenção principal deste trabalho é de contribuir, de forma simples, com esse tema. Ele não tem a pretensão de ser conclusivo, pois evidentemente muitos caminhos ainda existem para serem percorridos nessa área.

Quem sabe esta pequena amostra sugerida aqui neste estudo possa ser o início de um outro bem mais aprofundado do ponto de vista lingüístico, dado que temas mais relacionados com a história e a cultura italiana do primeiro imigrante têm sido privilegiados, ao passo que a questão da língua ainda é pouco explorada pelas pesquisas em geral. 


\section{REFERÊNCIAS BIBLIOGRÁFICAS}

BALDI, G.; GIUSSO, S.; RAZETTI M.; ZACCARIA, G.. Dal testo alla storia dalla storia al testo. Torino: Paravia, 2000.

BALHANA, A. P. Italianos no Paraná, 1987. In: DE BONI, Luis A. (Org.) A presença italiana no Brasil. Porto Alegre: EST Edições; Torino: Fondazione Giovanni Agnelli, 1987.

Cultural, 1978.

Santa Felicidade: uma paróquia vêneta no Brasil. Curitiba: Fundação . Santa Felicidade. Curitiba: Fundação Cultural, 1978.

. Presenza di comunità dialettali italiane in Brasile: aspetti sociali, economici $e$ demografici. In: LO CASCIO, V. (a cura di). L'italiano in America Latina. Firenze: Le Monnier, 1987.

BERRUTO, G. Sociolinguistica dellitaliano contemporaneo. Roma, La Nuova Italia Scientifica, 1987.

BETTONI, C. Italiano fuori d'Italia. In: Introduzione all'italiano contemporaneo: la variazione e gli usi. Bari: Laterza, 1993.

BEVILACQUA, P., CLEMENTI, DE A., FRANZINA, E., Storia dell'emigrazione italiana. Roma: Donzelli Editore, 2002.

BISSOLI, O. Memórias de um imigrante italiano. Vitória, 1979.

BORGES, L.. A imigração italiana em Morretes. Curitiba: Editora O Formiguero, 1990.

CANGI, N.; PICCINELLI, B.; VERI, L. Lontana terra. Milano: Terre di mezzo Editore, 2005. 
CAPRARA, L. S. de; MORDENTE, O. A. Panorama dellitaliano in San Paolo nel contesto plurilinguistico brasiliano. Revista de Italianística, 9: 1413-2079, 2004.

CASTRO, G. M. de Vestigi di lingua italiana: testimonianze da Pedrinhas Paulistas. Revista de Italianística, 7: 1413-2079, 2003.

CENNI, F. Italianos no Brasil. São Paulo: Edusp, 1975.

COLOGNESE, S. A. Associações Étnicas de italianos: Identidade e globalização. São Paulo: Itália Nova, 2004.

DE BONI, L. A.; COSTA, R.; TRENTO, A.. La presenza italiana nella storia e nella cultura del Brasile. Torino: Edizione della Fondazione Giovanni Agnelli, 1991.

DE FELICE, R. (a cura di) L'emigrazione italiana in Brasile, 1800 - 1978. Fondazione Agnelli, 1980.

DELLA VALLE, V.; PATOTA, G. L'italiano. Biografia di una lingua. Milano: Sperling e Kupfer Editori, 2006.

DE MAURO, T. Storia linguistica dell' Italia Unita. Bari: Laterza, 2002.

. Come parlano gli italiani. Firenze: La Nuova Italia, 1994.

FERRARINI, S. A imigração italiana na província do Paraná e o município de Colombo. Curitiba: Litero-Tecnica, 1973.

. Colombo: centenário da imigração italiana. Curitiba: Litero-Tecnica, 1979.

. Da Itália ao Paraná. Curitiba: EDUCA, 1989.

FRANCESCHINI, A. L'emigrazione italiana nell'America del Sud. Roma; Forzani e C. Tipografi Editori, 1908.

GRAZZI, E. II Brasile e l'emigrazione italiana. In: Politica Nazionale, febbraio/marzo 1923. 
GROSSI, V. Colonizzazione Europea al Brasile. Milano: Editrice Dante Alighieri, 1914.

GUAIGNINI, E. Studiare la Letteratura italiana di viaggio (e le guide) oggi in: Cadernos didaticos. Lingua cultura e literatura italianas, 1998.

La presenza italiana nella circoscrizione consolare di Curitiba. In: Presenza italiana in Brasile. I.C.I.B., Ambasciata d'Italia, Istituto Italiano di cultura di San Paolo.

LEPSCHY, L.; LEPSCHY, G. La lingua italiana. Storia, varietà dell' uso, grammatica. Milano: Bompiani, 1993.

MARCONE, N. Gli italiani al Brasile. Roma: Romana, 1877.

MARTINI, G. Origine e sviluppo della colonia di Santa Felicidade. Curitiba: Frattini e Cia.

Ministero degli Affari Esteri, Ministero della Pubblica Istruzione. L'italiano in America Latina, a cura di Lo Cascio, V., Firenze: Le Monnier, 1987.

MORDENTE, O. A. L'italiano a San Paolo. In: Loredana de Stauber Caprara; Letizia Zini Antunes. (Org.). O italiano Falado e Escrito.1.ed. São Paulo: Humanitas-Livraria, 1998.

OSTI GUERRAZZI, A.; SACCON, R.; VOLPATO PINTO, B.; Dal Secchia al Paraíba: l'emigrazione modenese in Brasile. Comune di Concordia sulla Secchia Istituto Storico di Modena: Cierre Edizioni, 2002.

PELLIZZETTI, Beatriz. Colonia Cecília: anarquistas no Paraná. In: DE BONI, L. A. A presença italiana no Brasil. Porto Alegre: Escola Superior de Teologia, 1987 p. 313332.

POLINARI, M. Cabeça do immigrante italiano. Curitiba, 2004.

PRETI, D. Análise de textos orais. São Paulo: Humanitas, 2003.

RAK, Michele. Gli italiani all'estero: 140 anni di fotografie delle comunità italiane. 2001. 
RASO, T. L'italiano parlato a San Paolo da madrelingua colti: Primi sondaggi e ipotesi di lavoro. Revista de Italianística, 7: 1413-2079, 2003.

ROMARIO, M. Terra e gente do Paranà. Curitiba: Editech, 1995.

SABATINI, F. L'italiano: dalla letteratura alla nazione. Firenze: Accademia della Crusca, 1997.

SCALABRINI, J. B. A emigração italiana na América. Est, Cepam, Ucs, 1979.

SERIANNI, L. Storia della lingua italian: il secondo ottocento. Bologna: II Mulino, 1990.

STELLA, G. A.; TETI, V. La nave della Sila: guida al museo narrante dell' emigrazione. Catanzaro : Soveria Mannelli, Rubbettino, 2006.

TRENTO, Ângelo. Do outro lado do Atlântico: um século de imigração italiana no Brasil. São Paulo: Nobel, 2000.

. In Brasile. In: BEVILACQUA P., CLEMENTI De A., FRANZINA E. (a cura di) Storia dell' emigrazione italiana. Arrivi. Roma: Donzelli, 2002, p. 3- 23.

TREVISAN, A.; POZENATO, J. C.; FARACO, S. Dalla'altra sponda: tre scrittori italo brasiliani. (Trad. Brunello Natale de Cusatis). Porto Alegre:Câmara de Comércio Italiana do Rio Grande do Sul; Venezia: Giunta Regionale/Segreteria Regionale Cultura e Istruzione 2002.

UGOLOTTI, Filippo. Italia e italiani in Brasile: note ed appunti. San Paolo, 1897.

VENEROSI PESCIOLINI, R. Le colonie italiane nel Brasile Meridionale: stati di Rio Grande do Sul, Santa Catarina e Paraná. Torino: Fratelli Bocca, 1914.

VILLA, Delisio. Storia dimenticata. Vicenza: Ente Vicentini nel mondo, 1997.

WACHOWICZ, R.. História do Paraná. Curitiba: Vicentina, 1982.

WEINREICH, U.. Lingue in contatto. Torino: Boringhieri, 1974. 


\section{APÊNDICE 1 - QUESTIONÁRIO}

1) Luogo ed anno di nascita?

2) Cosa si ricorda della sua città d'origine?

3) Che ricordi ha degli anni trascorsi in Italia?

4) Com'era la sua famiglia, da quante persone era composta?

5) Lei aveva studiato in Italia? Fino a quale classe?

6) In che anno è partito/a per venire qui in Brasile? Perché è partito/a?

7) È partito/a da solo/a o insieme alla sua famiglia, ai suoi amici?

8) Da dove è partito/a?

9) Che idea aveva del Brasile quando ha deciso di partire? Come se lo aspettava?

10) Che ricordi ha della nave? Come passava le giornate? Ha fatto amicizia?

11) Appena è sbarcato in territorio brasiliano qual' è stata la prima impressione che ha avuto?

12) Quale è stata la sua destinazione appena è sbarcato/a?

13) Quando ha raggiunto la città di Curitiba?

14) Quando e come ha imparato la lingua portoghese?

15) Mi racconti un po degli anni passati a Curitiba? Che lavoro ha fatto? Come si è integrato nella città?

16) Quali occasioni, se c'erano, aveva di continuare a parlare l' italiano?

17) Con chi lo parlava?

18) Si è sposato/a? Ha sposato una persona che faceva parte della comunità italiana oppure un/una brasiliano/a?

19) Che lingua parla quotidianamente? Che lingua ha insegnato ai suoi figli?

20) Quando è ritornato in Italia per la prima volta?

21) Come l'ha trovata?

22) Come vede l' Italia da Iontano?

23) Ritornerebbe in Italia per sempre?

24) Lei si sente più italiano/a o brasiliano/a? 